\title{
Sedimentological study of the Nikolčice Formation - evidence of the Middle Jurassic transgression onto the Bohemian Massif (subsurface data)
}

\author{
Slavomír NEHYBA ${ }^{1, *}$ and Vladimír OPLETAL ${ }^{2,1}$ \\ 1 Masaryk University, Faculty of Science, Institute of Geological Sciences, Kotlářská 2, 61137 Brno, Czech Republic \\ 2 MND, a.s., Úprkova 807/6, 69501 Hodonín, Czech Republic
}

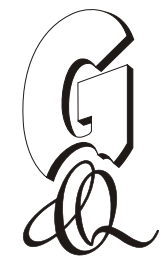

Nehyba, S., Opletal, V., 2017. Sedimentological study of the Nikolčice Formation - evidence of the Middle Jurassic transgression onto the Bohemian Massif (subsurface data). Geological Quarterly, 61 (1): 138-155, doi: 10.7306/gq.1335

\begin{abstract}
The Jurassic sedimentary succession along the eastern margin of the Bohemian Massif starts with mostly fluvial deposits of the Gresten Formation and continues after marine transgression with the deposition of the Nikolčice Formation (Middle Jurassic, Callovian). The provenance and depositional environment of the Nikolčice Formation showed that deposition occurred within offshore, transitional zone, shoreface, foreshore and littoral sand bar environments; however, shoreface and foreshore deposits dominate in the cores studied. The crystalline units along the eastern margins of the Bohemian Massif represent the primary source of deposits of the Nikolčice Formation. An important role was played by acidic and intermediate plutonites and highly metamorphosed metasedimentary rocks (granulite and amphibolite metamorphic facies), which indicates an advanced stage of erosion of the source area. The role of volcanic and intrusive rocks was small. The primary source was followed by an additional recycled source from older sedimentary rocks (especially the Moravo-Silesian Paleozoic deposits - the Lišeň Formation the Myslejovice Formation). A similarity of the source areas for the Nikolčice Formation and the underlying Gresten Formation was recognized. Identified differences in their source areas are mainly explained by varied erosional levels due to successive exhumation of the source Variscan orogen and possibly also by an expansion of the source area.
\end{abstract}

Key words: Nikolčice Formation, Middle Jurassic, provenance, shallow marine and nearshore depositional environment.

INTRODUCTION

The deposits of the Nikolčice Formation (Callovian; Eliáš and Wessely, 1990) were considered in years past as only a secondary target of oil and gas exploration in the Czech Republic. Therefore, no detailed study focusing explicitly on these strata was performed and all the published information concerning them can be found only in general regional geological papers (Picha et al., 2006) or at best in papers covering the full set of the Jurassic deposits in the Czech Republic (Adámek, 2002, 2005). After the acquisition of new 3D seismic survey of the area in which the deeper settings of the Nikolčice Formation (NF) forms one of the most prominent exploration targets for oil and gas, a detailed study of available borehole cores was performed to describe its depositional environment and sedimentological settings. The NF strata were deposited in the lower part of the complex Jurassic sedimentary sequence, above basal Jurassic deposits of the Gresten Formation, and they are usually overlain by Upper Jurassic Vranovice Unit carbonates and dolomites or directly by the Mikulov Marls.

This paper provides information about the depositional environment and source area of the NF.

* Corresponding author, e-mail: slavek@sci.muni.cz Received: July 29, 2016; accepted: November 24, 2016; first published online: December 15, 2016

\section{GEOLOGICAL SETTING}

The area under study is located along the eastern margin of the Bohemian Massif. A long period of hydrocarbon exploration provided data about the geological history of the area. A generalized stratigraphic scheme is shown in Figure 1 and the location of the area under study in Figure 2. The basement of the area under study is formed by a complex of Cadomian magmatic rocks known as the Brno Massif, which is overlain by Paleozoic, Mesozoic and Cenozoic deposits. The sedimentation began by very limited (within the northern part of the study area) Cambrian basal clastic deposits (Jachowicz and Prichystal, 1997; Vavrdová et al., 2003), which are followed by basal clastic deposits of Devonian age (Nehyba et al., 2001; Wojewoda et al., 2015). However, as the lithology of these two units is very similar, it is locally difficult to distinguish between them without micropalaeontological information. During the Middle Devonian, the clastic sedimentation was succeeded by shelf carbonate deposition (Moravian Karst Facies), which continued to the earliest Pennsylvanian (Tournaisian, lower part of the Visean) (Kalvoda et al., 2008). This sequence was subsequently overthrust by the Pennsylvanian Culmian facies flysch wedge during Variscan orogenesis (Cizek and Tomek, 1991). During the Mississippian the area of study became a molasse zone of the Variscides, which was probably a direct southern continuation of the Upper Silesian Coal Basin (Opletal and Filák, 2013).

After a hiatus the Jurassic sedimentation began, often with a noticeable angular unconformity seen in seismic images be- 


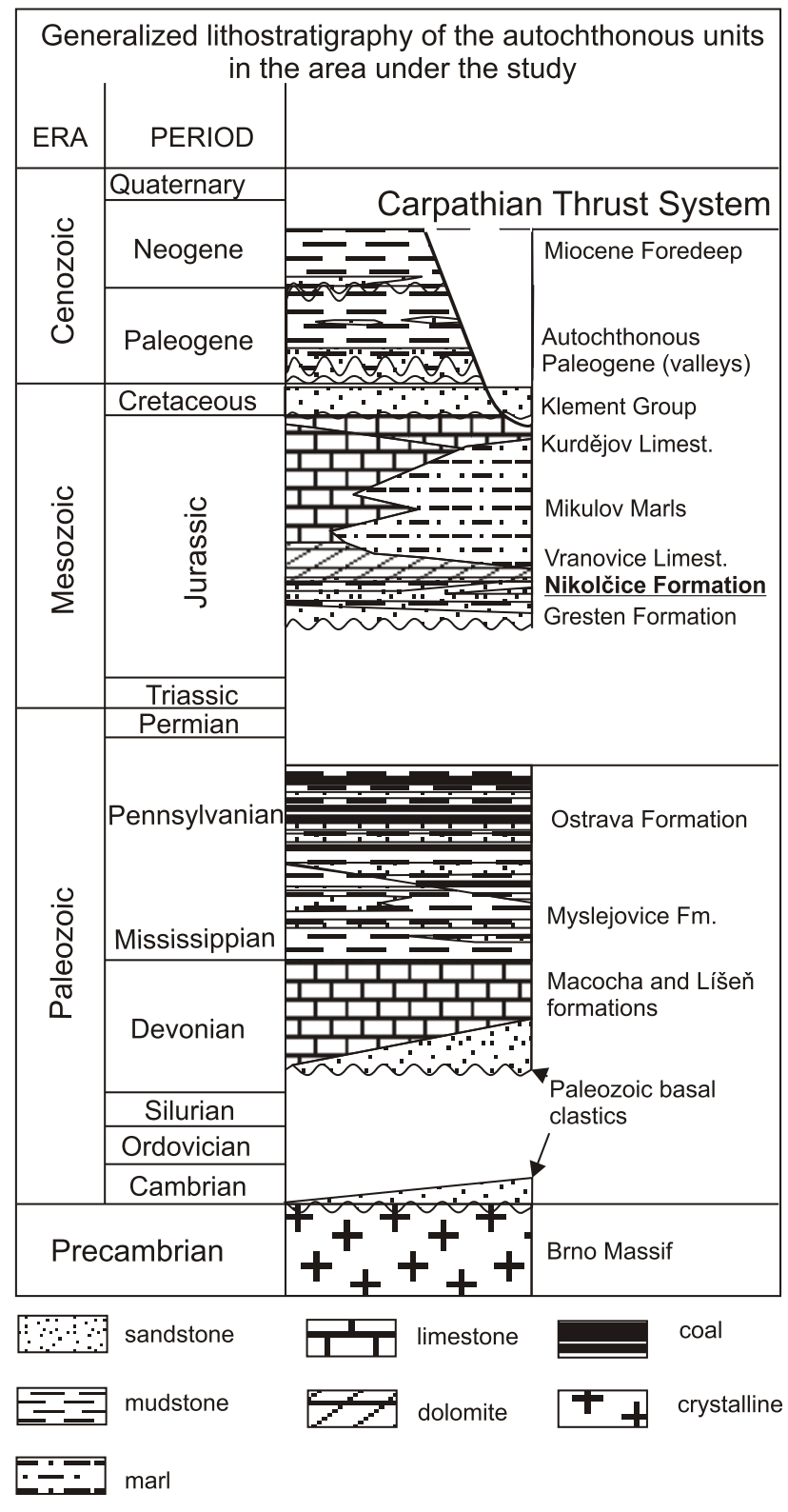

Fig. 1. Generalized stratigraphic scheme of the autochthonous units in the area under study (modified after Picha et al., 2006)

tween Jurassic and older rocks. The extent of the sedimentary basin formed during the Jurassic is indicated by the continuous sequence of Jurassic deposits in many boreholes from the Austrian border in the south-west towards the Ždánice area in the north-east and has also been interpreted using 3D seismic data. The whole sequence begins with Bajocian-Bathonian (Aalenian-Bathonian in Austria) deposits of the Gresten Formation with its deltaic and prodeltaic deposits in Austria (Wessely, 1988) and mostly fluvial deposits in the Czech Republic (Nehyba and Opletal, 2016). Then the sequence continues after transgression with the sandstones of the NF studied (Callovian), which usually conformably overlies the Gresten Formation. Locally synsedimentary tectonics also played a role during the deposition of the NF in the Czech Republic, as seen in the Damborice Field area (the largest Jurassic oil field in the Czech Republic). There, increased thickness of the NF in the hangingwall area was interpreted using 3D seismic data. However, the thickness of the older Gresten Formation is similar in both foot-wall and hanging-wall blocks (Fig. 3). The NF can be correlated with the Hoeflein Beds (Dolomitische Quarzarenitserie) in Austrian territory (Eliáš and Wessely, 1990). There, stable platform conditions are documented during the Callovian and the Hoeflein Beds are uniform in thickness (Anonymous, 1992). The lithology of the NF and Hoeflein Beds varies laterally. Carbonate influence dominated at the start of deposition, especially in the Pavlov Waschberg Block; sandstones prevail in the southern part of the Central Moravian Block (Adámek, 2005). In Austria the Hoeflein Beds are divided into two units, an upper member formed by slightly sandy dolomites, and a lower member with prevailing silicified sandy dolomites with thin chert bands and nodules (Anonymous, 1992). Two developments of the NF have been recognized in the area of southern Moravia. The first one is represented by sandy dolomites and medium- to coarse-grained dolomitic sandstones and is typical of the prospection areas of southern Moravia. The second one, formed by arkosic to quartzose sandstones with a low content of carbonates, is typical of the central Moravia prospection areas (Adámek, 1986, 2002, 2005). Recent 3D seismic data support the gradual transition of fluvial facies of Gresten Formation to the NF (Picha et al., 2006) over the angular discontinuity at the base of the NF (Adámek, 2002).

Further transgression turned clastic deposition of the NF into a gradual development of predominantly carbonate depositional environment (the Vranovice Limestones and Dolomites) during the Oxfordian, followed by tectonic downwarping of the Jurassic passive continental margin/shelf in the SE part of the area. This maintained shallow marine carbonate deposition in the NW (the Altenmarkt Group) and opened the deeper marine basin for sedimentation of the Mikulov Marls in the SE. The Mikulov Marls pass upwards into a formation of organodetrital limestones and dolomites called the Kurdějov Limestones, and sedimentation continued with organodetrital, partly dolomitised limestones - the Ernstbrunn Limestones, which are equivalent to the allochthonous Ernstbrunn Limestones known from the Outer Klippen in northeastern Austria and southern Moravia (Picha et al., 2006). In the area of study the Early Cretaceous sedimentation of "oncoidal limestones" defined as the Nové Mlýny Limestones is known only from the Nové Mlýny 2 borehole (Adámek, 1986) and therefore the next sedimentary event with significant areal extent is documented during the Late Cretaceous (Cenomanian-Maastrichtian), when marine incursion again flooded the majority of the European Platform. The basal glauconitic sandstones pass into calcareous claystones and siltstones with beds of sandy limestones and sandstones. In Austria the Upper Cretaceous is known as the Klement Group. In the Czech Republic this sedimentation is rather limited, beginning in the Turonian and continuing to the Early Campanian (Stráník et al., 1996). Štelcl et al. (1977) evaluated the petrography of the Mesozoic deposits from the eastern slopes of the Bohemian Massif.

During the Paleogene the halfgraben of Nesvačilka Palaeovalley was opened and, in both the Nesvačilka and Vranovice palaeovalleys, major erosion is present with subsequent formation of deep-water deposits. This erosion has unfortunately made impossible the study of the Jurassic deposits across the entire area, and especially in the eastern part, locally only erosional relics are present and available for study. Finally, the area underwent extensive peneplenization and subsequent deposition during the thrusting of the Western Carpathians and related formation of the Carpathian Foredeep (Miocene peripheral foreland basin; Nehyba and Šikula, 2007). 


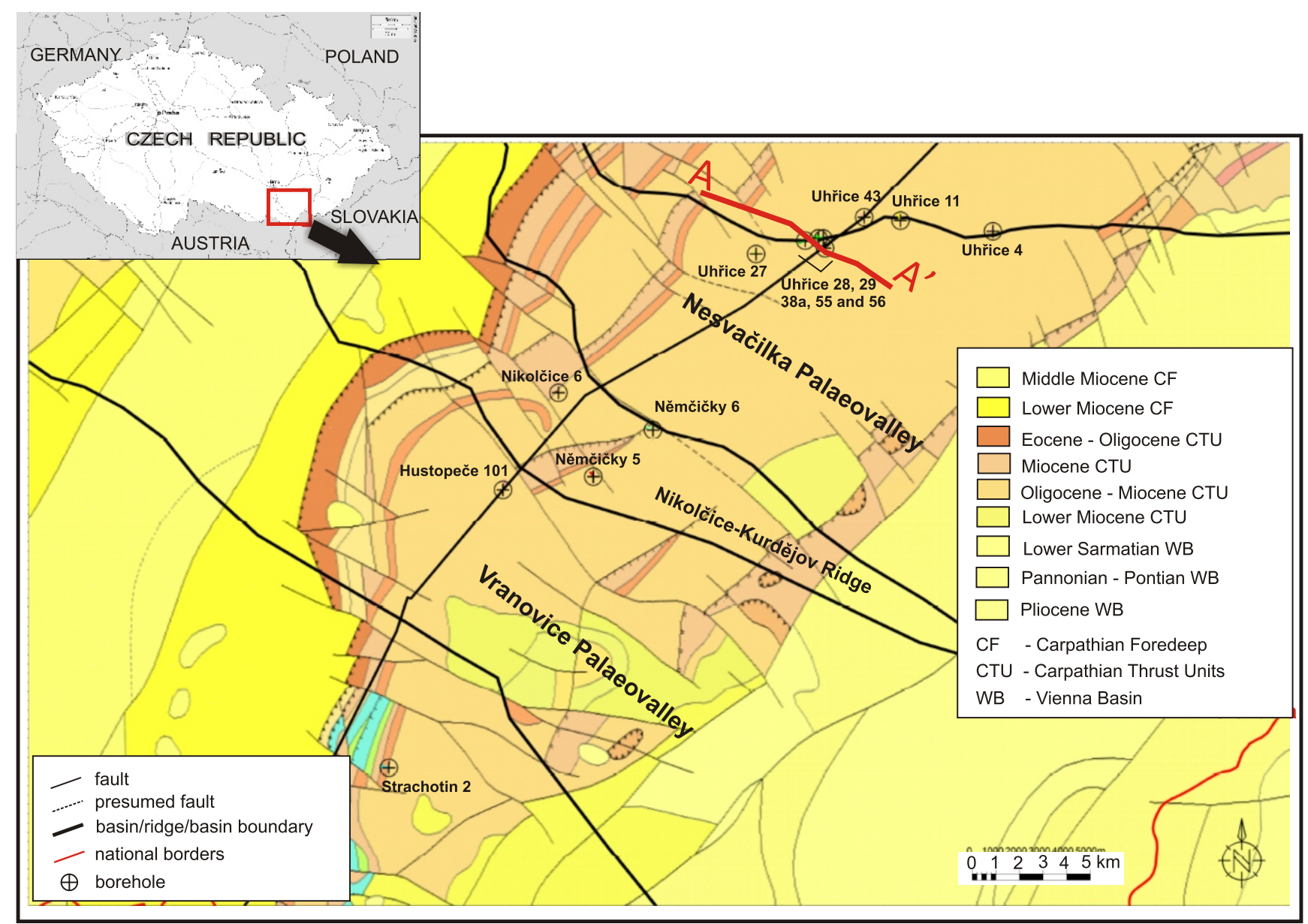

Fig. 2. Geographic location of the area under study with positions of evaluated boreholes and cross-section

\section{METHODS OF STUDY}

Lithofacies analysis is based on the sedimentological study of borehole cores, following Walker and James (1992) and Tucker (1988). Cores from the following petroleum industry boreholes - Hustopeče 101, Strachotín 2, Němčičky: 5, 6, Nikolčice 6, Uhrice: 4, 11, 27, 28, 29, 38a, 43, 55 and 56 - were available for the study (see Fig. 2). The quality and thickness of the cores varies greatly. The greatest thickness of the cores was almost $11 \mathrm{~m}$; however, they mostly reach only a few metres. Altogether $>76 \mathrm{~m}$ of core section was logged. Further information was provided by evaluation of the available ("standard") wire-line log techniques i.e. spontaneous potential (SP), resistivity (Rag 2, 12) and gamma-ray (gamma-API) (Rider, 1986).

Results of the provenance analyses are based on a combination of pebble analyses, evaluation of sandstone thin-sections and heavy mineral studies. Pebble analyses are based on a study of 9 samples from 5 boreholes. Assemblages of heavy minerals (95 analyses) were evaluated in the $0.063-0.125 \mathrm{~mm}$ grain-size fraction. Garnet, zircon, and rutile represent the most common heavy minerals in the NF, being relatively stable during diagenesis and having a wide compositional range. For that reason, they have been further evaluated in detail. Zircon studies (external morphology, colour, presence of older cores, inclusions and zoning, typology, elongation) were carried out on 285 grains. Electron microprobe analysis of garnet (103 grains) and rutile (21 grains) was done on a CAMECA SX electron microprobe analyser (Faculty of Science, Masaryk University, Brno).

\section{RESULTS}

\section{FACIES ANALYSIS}

Seventeen lithofacies were distinguished according to grain size and sedimentary structures. The description of these lithofacies is shown in Table 1 and examples are given in Figure 4. The facies indices proposed in Table 1 are used for facies identification in the following text. Five lithofacies groups - coarse-grained, sandstone, heterolithic, fine-grained and organic-rich - can be recognized. The coarse-grained lithofacies comprise $\mathrm{Gm}, \mathrm{Gi}$ and $\mathrm{Sg}$ lithofacies. The role of these lithofacies varies greatly in the cores studied. While completely missing in most cores, in three cores (Němčičky 5 , Uhrice 29 and 43 boreholes), they constitute $17.3-25.7 \%$ of the logged profile, and in two cores (Uhřice 55 and Uhřice 11 boreholes) they represent the complete profile. The sandstone group of lithofacies contains lithofacies Sd, Sp, Sb, Sr, Sm, SI and Sh. Sandstones have been commonly dolomitized (which 


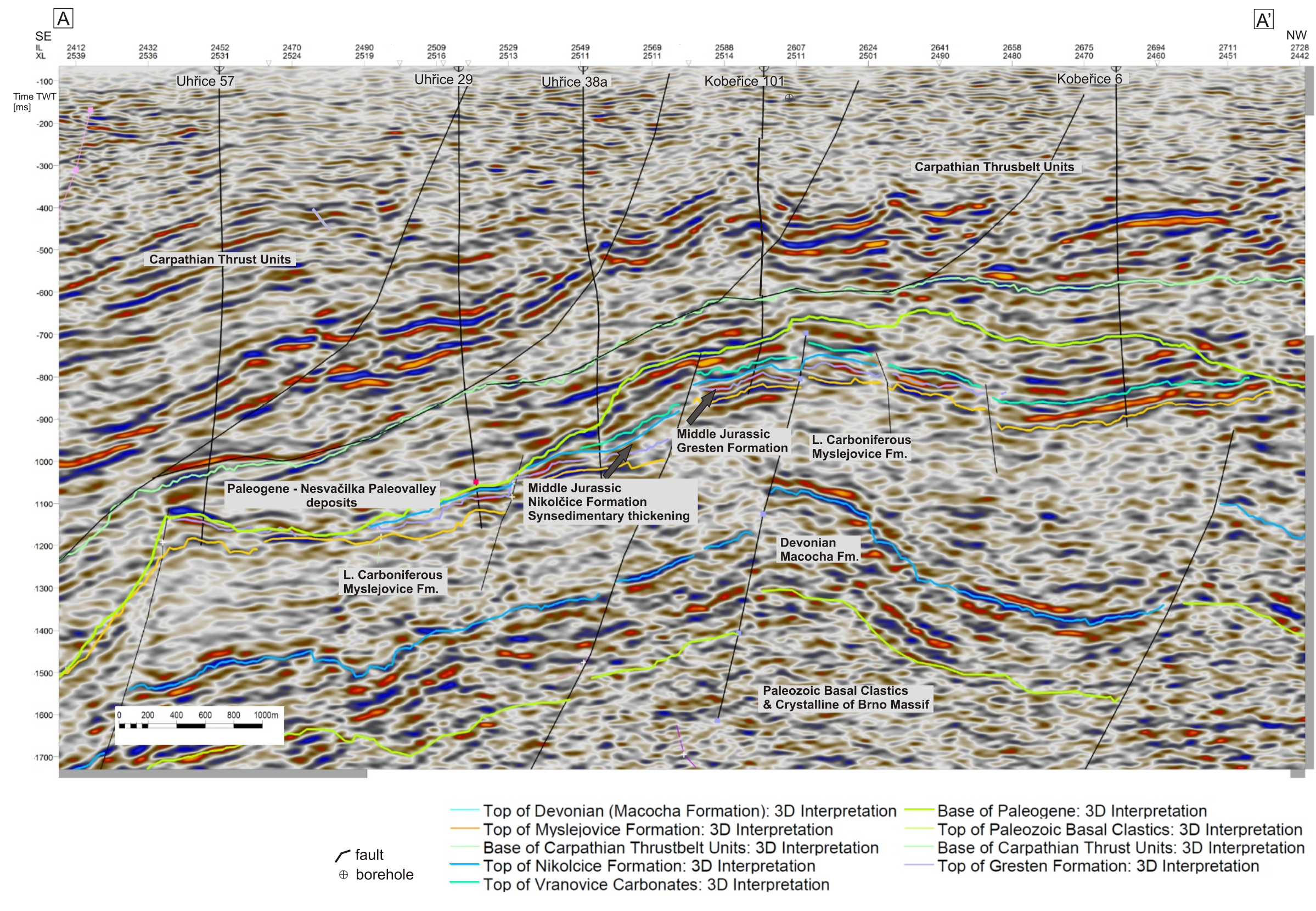

Fig. 3. A geoseismic cross-section aligned SW-NE in the central part of the area under study 
Descriptive summary list of lithofacies of the Nikolčice Formation distinguished in the cores studied

\begin{tabular}{|c|c|}
\hline $\begin{array}{l}\text { Facies } \\
\text { symbol }\end{array}$ & Description \\
\hline Gm & $\begin{array}{l}\text { Light grey or whitish grey fine-grained conglomerate. Pebbles are both rounded and subrounded and reach max. } 3 \mathrm{~cm} \text {, mostly } \\
\text { up to } 1 \mathrm{~cm} \text { across. Conglomerate has massive appearance. Multiple amalgamated beds with alternation of conglomerate } \\
\text { matrix supported/or pebbly sandstone and conglomerate with clast support fabric. No preferred orientation of pebbles. Base } \\
\text { of the beds is mostly sharp and often erosive. Matrix is represented by arkosic sandstone. }\end{array}$ \\
\hline $\mathbf{G i}$ & $\begin{array}{l}\text { Light grey fine-grained conglomerate. Pebbles are mostly rounded to subrounded. They reach max. } 2 \mathrm{~cm} \text { across, however, } \\
\text { granules and small pebbles up to } 5 \mathrm{~mm} \text { dominate. Coarse tail inverse grading is typical. Both base and top of beds are sharp. }\end{array}$ \\
\hline $\mathrm{Sg}$ & $\begin{array}{l}\text { Two subfacies of poorly sorted sandstones have been recognized. Subfacies Sg1 represents coarse- to very coarse-grained } \\
\text { sandstone along the base, fining upwards into fine grained sandstone, inclined parallel stratification, locally bioturbated, } \\
\text { floating granules up to } 4 \mathrm{~mm} \text { across, locally water escape structures. Subfacies Sg2 represents medium to coarse, very } \\
\text { coarse-grained sandstone with admixture of subrounded quartz pebbles up to } 1 \mathrm{~cm} \text { across (pebbles are more common along } \\
\text { the set bases), locally irregular flasers of mudstone, structureless. Preferred orientation or distribution of coarse clasts was } \\
\text { not recognized. }\end{array}$ \\
\hline Sp & $\begin{array}{l}\text { Light brown, light grey, medium- to coarse-grained sandstones, poorly sorted. Planar cross-stratified with low angle } \\
\text { of inclination. Common occurrence of rounded to subrounded granules up to } 4 \mathrm{~mm} \text { across. Typical preferred orientation } \\
\text { of the long axis of these clasts parallel to stratification. }\end{array}$ \\
\hline Sm & $\begin{array}{l}\text { Light grey to grey, brown grey, fine, fine to medium, medium or rarely medium- to coarse-grained sandstone, relative poorly } \\
\text { sorted, structureless. Varied amount of admixture of coalified organic matter. A few thin discontinuous irregular flasers of dark } \\
\text { grey siltstone or slate coal. Varied intensity of bioturbation. Locally isolated coarse clasts }(2 \mathrm{~mm}-1.6 \mathrm{~cm}) \text { irregularly distributed. }\end{array}$ \\
\hline $\mathrm{Sr}$ & $\begin{array}{l}\text { Light grey or yellow grey, medium-grained sandstone with rare and scattered occurrence of coalified organic matter. } \\
\text { Ripple cross-lamination. }\end{array}$ \\
\hline $\mathrm{Sb}$ & $\begin{array}{l}\text { Bioturbated sandstone, intensity of bioturbation varied, commonly very intense and complete loss of primary structures. Locally } \\
\text { preserved resmains of inclined or horizontal plane parallel stratification. Two subfacies have been recognized: subfacies Sb1 } \\
\text { represents light grey to grey irregularly grained (poorly sorted) generally fine sandstone, bioturbated (mostly ichnofacies } \\
\text { Skolithos, rarely Cruziana), in places occurrence of irregularly distributed quartz granules and small subrounded to rounded peb- } \\
\text { bles (up to } 5 \mathrm{~mm} \text { across). Fragments of coalified plant debris up to } 3 \mathrm{~mm} \text { in size. Subfacies Sb2 represents light grey to grey, } \\
\text { fine, medium to coarse, coarse-grained sandstone, well-sorted. Beds have erosive bases and fining upward trend with coarse } \\
\text { sand along the base. Locally occurrence of discontinuous flasers of mudstone rich in plant fragments to the top of the beds. }\end{array}$ \\
\hline SI & $\begin{array}{l}\text { Light grey or brown, fine, fine to medium or medium-grained sandstone, relative well-sorted, plane parallel stratification, in } \\
\text { places inclined (low angle of inclination). Rhytmic variations in the grain size of individual laminae. Rare occurrences of trace } \\
\text { fossils (Skolithos ichnofacies). In places occurrences of shell fragments or flasers of siltstone enriched in coalified plant frag- } \\
\text { ments, or scattered granules up to } 3 \mathrm{~mm} \text { irregularly distributed. }\end{array}$ \\
\hline Sd & $\begin{array}{l}\text { Light grey, brown grey, fine, fine to medium-grained sandstone with numerous soft sediment deformation structures } \\
\text { (convolute stratification, dish and pipe structures, convolute folds), which almost obliterated the primary sedimentary structure } \\
\text { of planar stratification. In places occurrence of scattered granules or small pebbles (up to } 5 \text { mm) mostly along the bed bases, } \\
\text { or irregular laminae of dark grey mudstone. Locally erosive base of the beds. }\end{array}$ \\
\hline Sh & $\begin{array}{l}\text { Light grey fine to medium-grained sandstone with undulose planar lamination or hummocky cross-stratification. } \\
\text { Relative well-sorted. }\end{array}$ \\
\hline H1 & $\begin{array}{l}\text { Alternation of irregular laminae of dark grey clayey siltstone rich in coalified plant fragments and fine to very fine light grey } \\
\text { sandstones. Sandstone is more common and forms thicker beds than siltstone. Plane parallel lamination with fragments of } \\
\text { coalified plant stems is typical of sandstones. Rarely bioturbated - low index of bioturbation. Flaser stratification. }\end{array}$ \\
\hline $\mathrm{H} 2$ & $\begin{array}{l}\text { Dark grey clayey siltstone rich in coalified plant fragments with irregular lenses and laminae of medium- to coarse-grained } \\
\text { sandstone, poorly sorted. Lenticular stratification. }\end{array}$ \\
\hline MI & $\begin{array}{l}\text { Dark grey clayey siltstone to silty claystone, plane parallel lamination. Varied role of bioturbation - low index of bioturbation, } \\
\text { Rare laminae of very fine sandstone. }\end{array}$ \\
\hline Mf & $\begin{array}{l}\text { Monotonous dark grey to black-grey mudstone, massive to poorly distinct plane parallel lamination. Both non-calcareous and } \\
\text { calcareous. Locally irregular admixture of fine white mica or very fine sand, rare shell debris, locally numerous fractures. } \\
\text { Conchoidal fracture. Locally trace fossils (Chondrites ichnofacies). }\end{array}$ \\
\hline Mm & $\begin{array}{l}\text { Dark grey mudstone, structureless. Poorly sorted, varied occurrence of irregularly distributed grains of very fine sand, rarely } \\
\text { coalified plant fragments. }\end{array}$ \\
\hline Sc & $\begin{array}{l}\text { Dark grey very fine sandstone, poorly sorted with flasers or irregular discontinuous laminas of black shiny coal. Lenticular or } \\
\text { planar stratification, in places occurrence of quartz granules up to } 3 \mathrm{~mm} \text { across. Facies forms irregular lensoidal beds, which } \\
\text { are about } 3 \mathrm{~cm} \text { thick. }\end{array}$ \\
\hline Mc & $\begin{array}{l}\text { Dark grey to black-grey silty mudstone very rich in coalified organic matter with large fragments of plant stems. Slate coal. } \\
\text { Common planar to slightly undulose lamination. Locally alternation of laminae of siltstone rich in coalified organic matter and } \\
\text { laminas or irregular lenses of black shiny coal. Mostly form only several centimetres thick beds. Both tops and bases of the } \\
\text { beds are irregular. Beds are commonly plastically deformed. }\end{array}$ \\
\hline
\end{tabular}

affected both the matrix and the grains). Facies analysis was targeted only on the cores where dolomitisation did not completely obliterate the primary sedimentary structures. The sandstone group of lithofacies mostly dominates in the cores studied (Hustopeče 101, Nikolčice 6, Uhřice: 24, 27, 29, 38a, 43 boreholes) forming 50 to $100 \%$ of the succession there. However, in some cores (Uhrice 28 and 56 boreholes) it represents only 19.5 to $22.9 \%$, or sandstones are completely missing (Uhřice: 38, 55 and 11 boreholes). The group of heterolithic litofacies comprises lithofacies $\mathrm{H} 1$ and $\mathrm{H} 2$. They have been recognized in several cores (Hustopeče 101, Uhrice: 28,29 and $38 \mathrm{~A}$ boreholes), where they constitute 3.6 to $38.5 \%$ of the section. This lithofacies group is missing in all other cores studied. The group of fine-grained lithofacies comprises lithofacies MI, Mm and Mf. These have been identified in cores from the Hustopeče 101, Uhřice: 29, 38A and 56 boreholes, where they form 1.1 to $73.8 \%$ of the logged section. The group is missing in all other logged cores/boreholes. The 

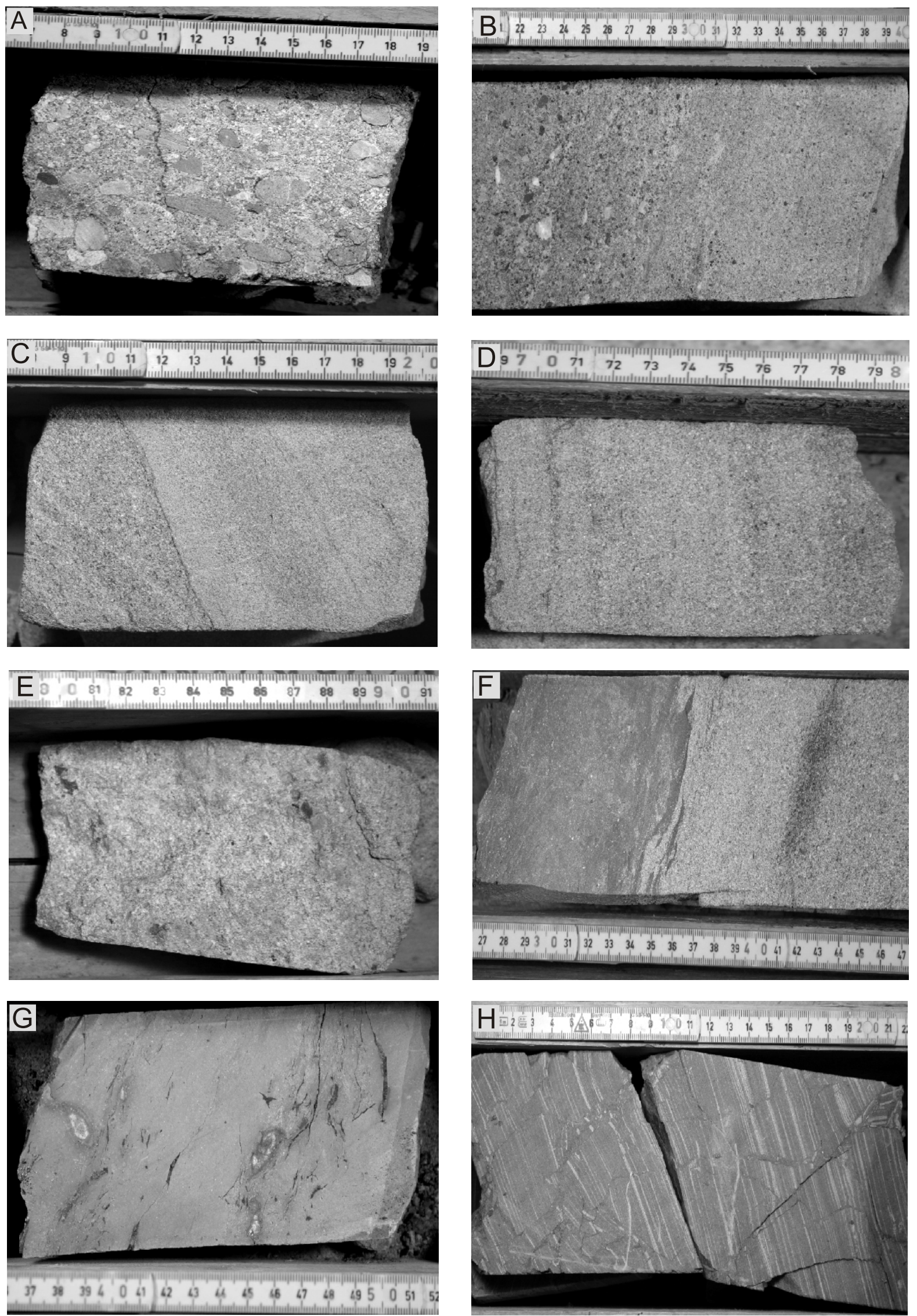

Fig. 4. Selected examples of lithofacies

A - facies Gm, B - facies Sg1, C - facies Sp, D - facies SI, E - facies Sd, F - facies SI and Mm, $\mathbf{G}$ - facies $\mathbf{M c}, \mathbf{H}$ - facies $\mathrm{Ml}$ 
group of organic-rich lithofacies comprises lithofacies Sc and Mc. Their representation was very small. They have been identified in only three cores (Uhřice 29 and 38A boreholes) and even there they constitute only 1.1 and $1.4 \%$ of the profile respectively.

The lithofacies have been combined, based on their spatial grouping within the cores into four facies associations (FA), which also constitute depositional environments. These FA are:
FA I - marine offshore deposits, FA II - deposits of the sublittoral offshore-transition and lower shoreface deposits, FA III shoreface and foreshore deposits, and FA IV deposits of littoral bars. FA III was further subdivided into sub-associations. The distribution of both lithofacies and facies associations significantly differs in the cores/boreholes studied and is marked in the sedimentological core logs (Fig. 5-8).

\section{Borehole Uhřice 29}

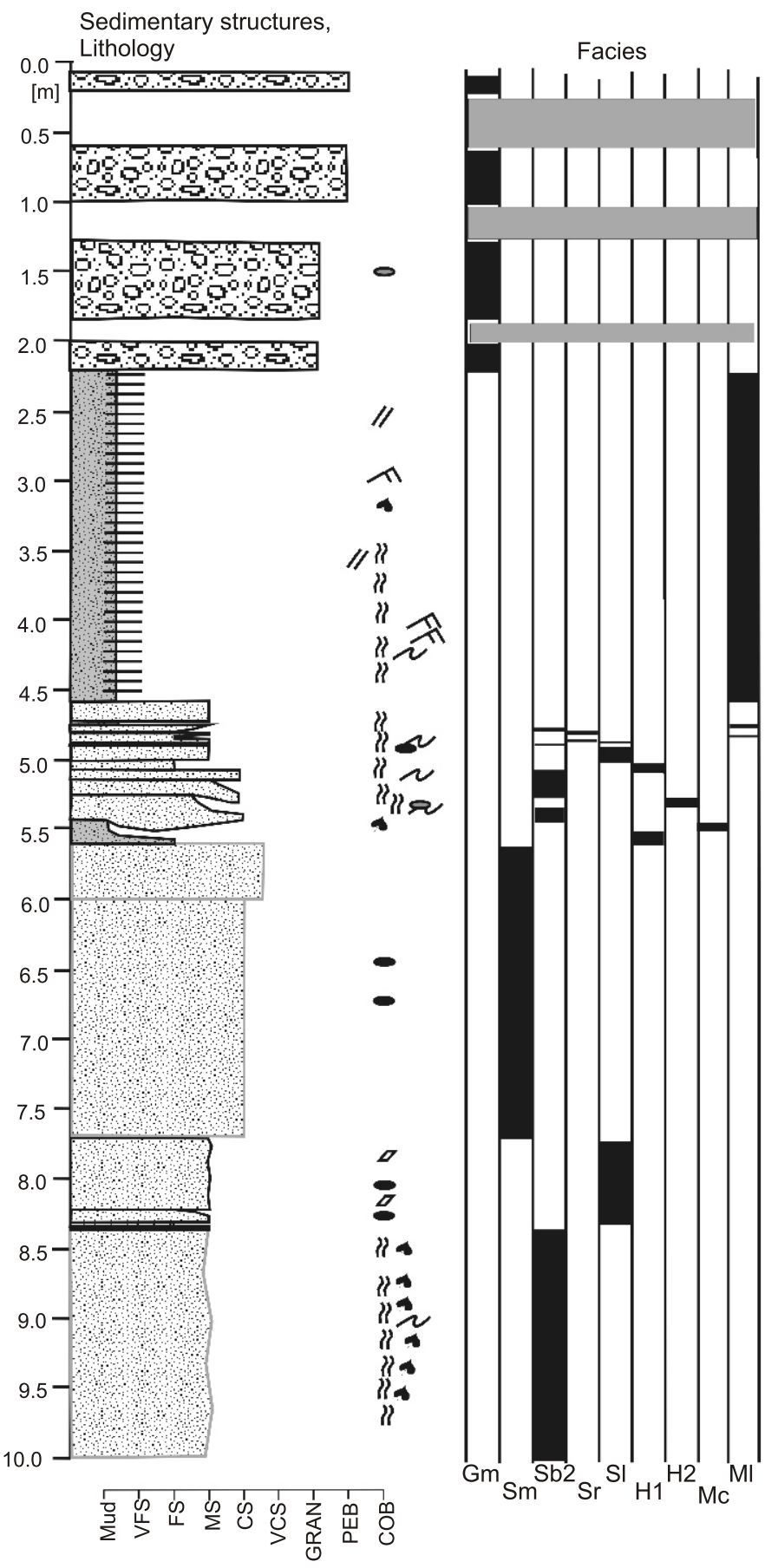

Facies association

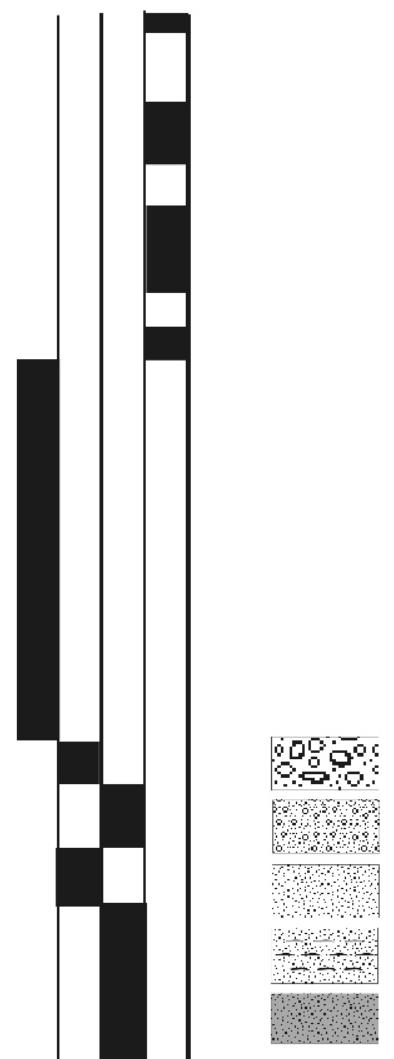

conglomerate gravelite, pebbly sandstone sandstone

sandstone with laminae of slate coal or mudstone intraclasts sandy mudstone

N ripple cross-lamination

$\varnothing$

- intraclasts of coal

- intraclats of mudstone

- plant remnants

$\sim$ soft sediment deformations

tectonic deformations

$\boldsymbol{\nabla}$ concretions

missing core

facies

Fig. 5. Sedimentological core logs of the Nikolčice Formation from borehole Uhřice 29

The logs show the stratigraphic distribution of sedimentary facies (letter code as in Table 1) and distinction of facies associations (FA I-IV); VFS - very fine sand, FS - fine sand, MS - medium sand, CS - coarse sand, VCS - very coarse sand, GRAN - granules, PEB - pebbles, COB - cobbles 
Borehole Uhřice 38 a

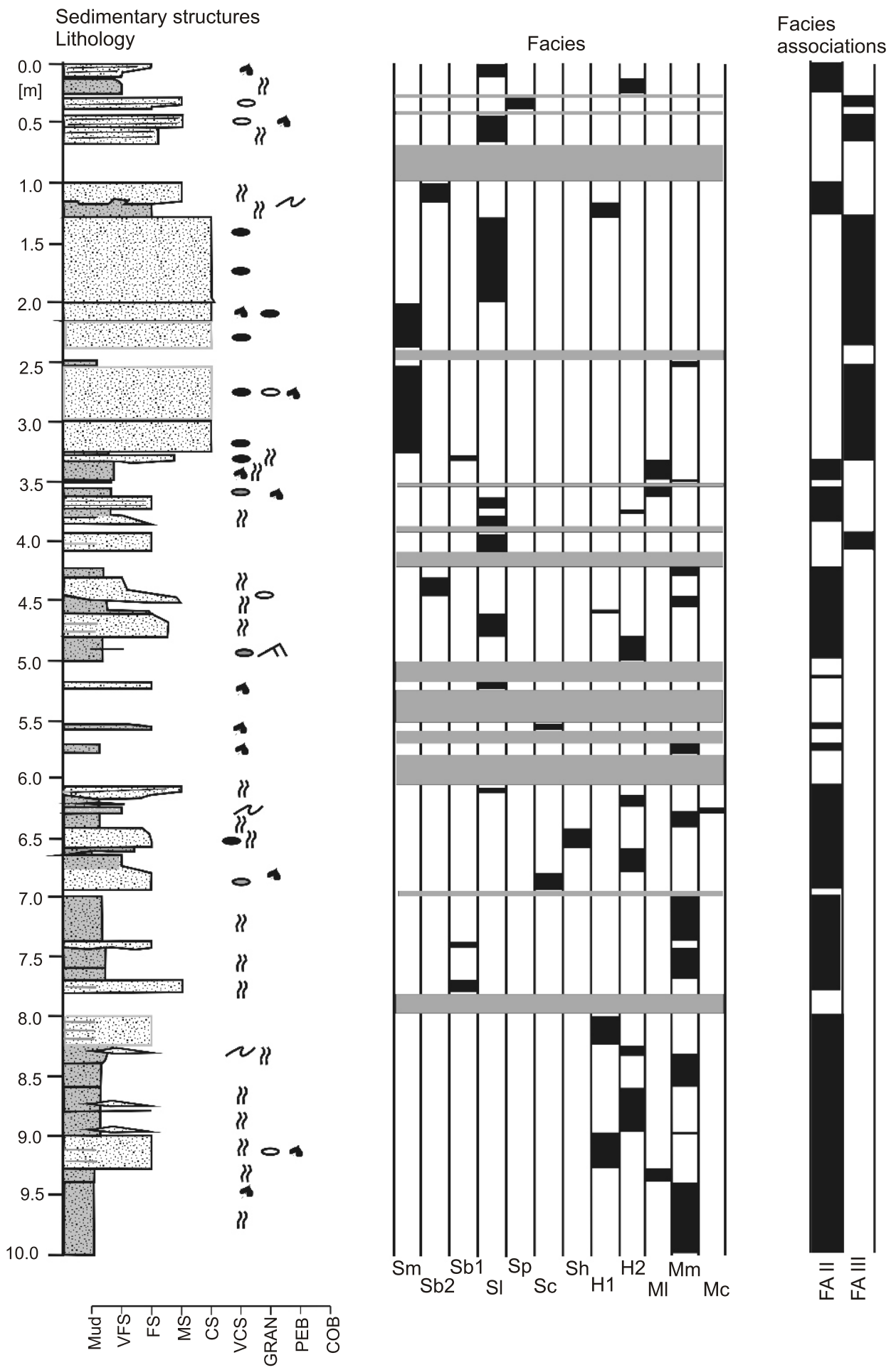

Fig. 6. Sedimentological core logs of the Nikolčice Formation from borehole Uhřice 38a

The logs show the stratigraphic distribution of sedimentary facies (letter code as in Table 1) and distinction of facies associations (FA II, III); for other explanations see Figure 5

\section{FACIES ASSOCIATION I}

FA I is formed by a fine-grained and heterolithic lithofacies (MI, Mm, Mf and H2). Thicker beds of FA I were recognized in three boreholes and formed $7.8 \%$ of the cores studied.
Interpretation: dominant fine-grained deposition reflects processes such as suspension, flocculation of pelitic particles or waning currents, which points to quiet conditions and a flat bottom. These conditions were repeatedly disturbed by sudden input of sand. Similarly, bioturbation of only some beds and an 
Borehole Uhřice 43
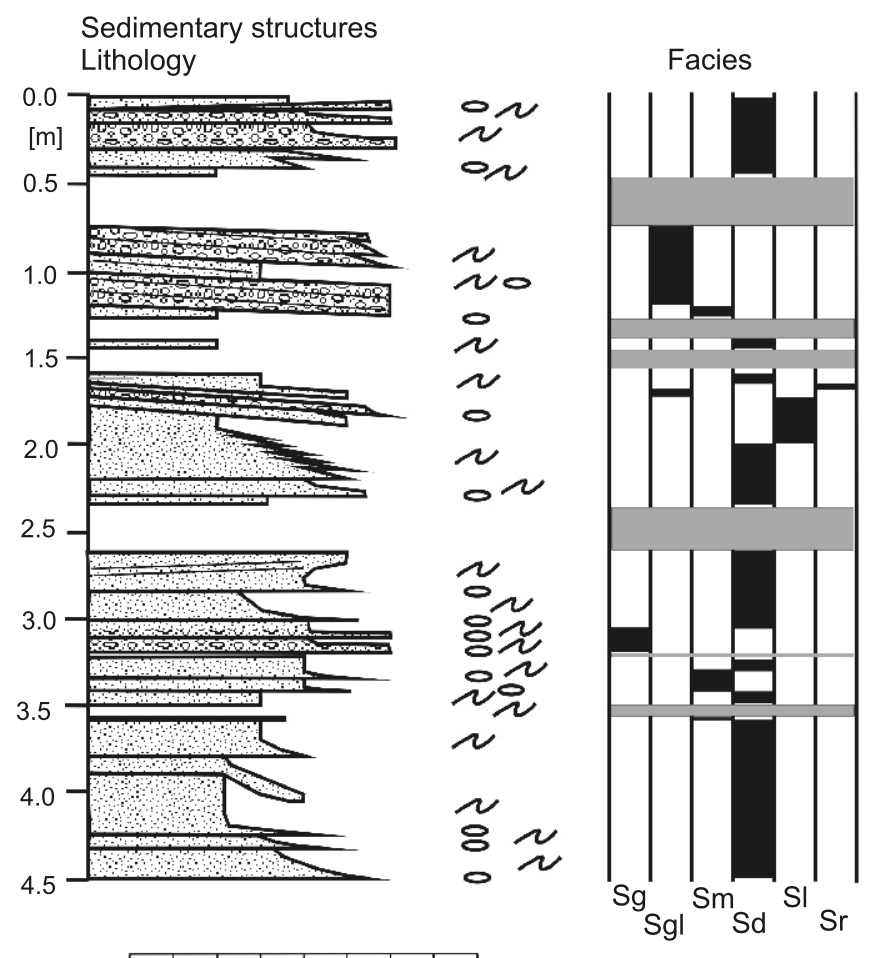

Facies associations

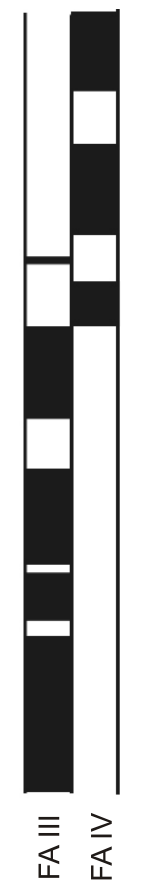

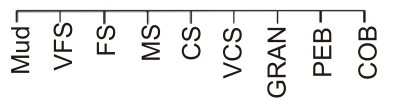

Fig. 7. Sedimentological core logs of the Nikolčice Formation from borehole Uhřice 43

The logs show the stratigraphic distribution of sedimentary facies (letter code as in Table 1) and distinction of facies associations (FA III, IV); for other explanations see Figure 5

absence of trace fossils in other ones reveals variations in conditions suitable for colonisation, which may have been connected with differences in input of clastic material, variations in organic content, chemistry, salinity, and temperature. Input of clastic material is inferred to have been connected mostly with storm activity, which can transport grain of various sizes below the shoreface base and such clasts are here commonly also preserved during fair weather conditions. FA I is interpreted as representing shallow marine offshore conditions.

\section{FACIES ASSOCIATION II}

FA II is represented by a dominance of heterolithic facies and by beds of lithofacies $\mathrm{H} 1, \mathrm{H} 2, \mathrm{Ml}, \mathrm{Sb}$, Sh and SI, with very rare occurrences of $\mathrm{Mc}$ and Sc. FA II is relative common and forms $20.8 \%$ of the logged cores.

Interpretation: heterolithic facies and rhythmic deposition reflect alternation of conditions of mostly quiet deposition (suspension, flocculation of pelitic particles, waning currents) on a relatively flat bottom and more dynamic conditions with an undulating bottom (ripples, small dunes). Muddy flasers may indicate tidal processes; however, clear evidence of tidalites was not recognised. Occurrences of lithofacies SI and Sh are connected with combined flows and storm activity, so we can suppose deposition above the base of storm waves. Bioturbation
(Sb) points to suitable conditions for bottom colonisation. FA II is interpreted as deposits of a sublittoral offshore-transition and lower shoreface (Clifton, 1981, 2006; Hampson, 2000). Lower shoreface deposits typically consist of fine sands intercalated with layers of silt and sandy mud. Planar laminated beds are obliterated here by bioturbation (Reinson, 1984).

Occurrences of organic-rich beds (Sc, Mc) point to the primary formation of plant material in terrestrial/backshore environments, then its erosion and redeposition into the adjacent marine basin. Rare increased organic material delivery into the basin and dominant clastic deposition may be explained by several factors (climate or palaeogeography). We can postulate the proximity of deltaic sediment delivery and longshore transport of the organic material.

\section{FACIES ASSOCIATION III}

FA III represents the most dominant association, recognized in the majority of cores and forming $62.9 \%$ of them. FA III is formed of sandstone lithofacies $\mathrm{Sm}, \mathrm{Sb}, \mathrm{Sl}, \mathrm{Sh}, \mathrm{Sr}, \mathrm{Sd}, \mathrm{Sg}$. FA III can be subdivided into two sub-associations based on the relative occurrence of individual lithofacies. Sub-association FA IIla is typified by a dominant role of lithofacies SI and the occurrence of $\mathrm{Sr}$ and commonly forms the upper portion of the thick beds of FA III. Lower portions of the beds of FA III are com- 
Borehole Hustopeče 101

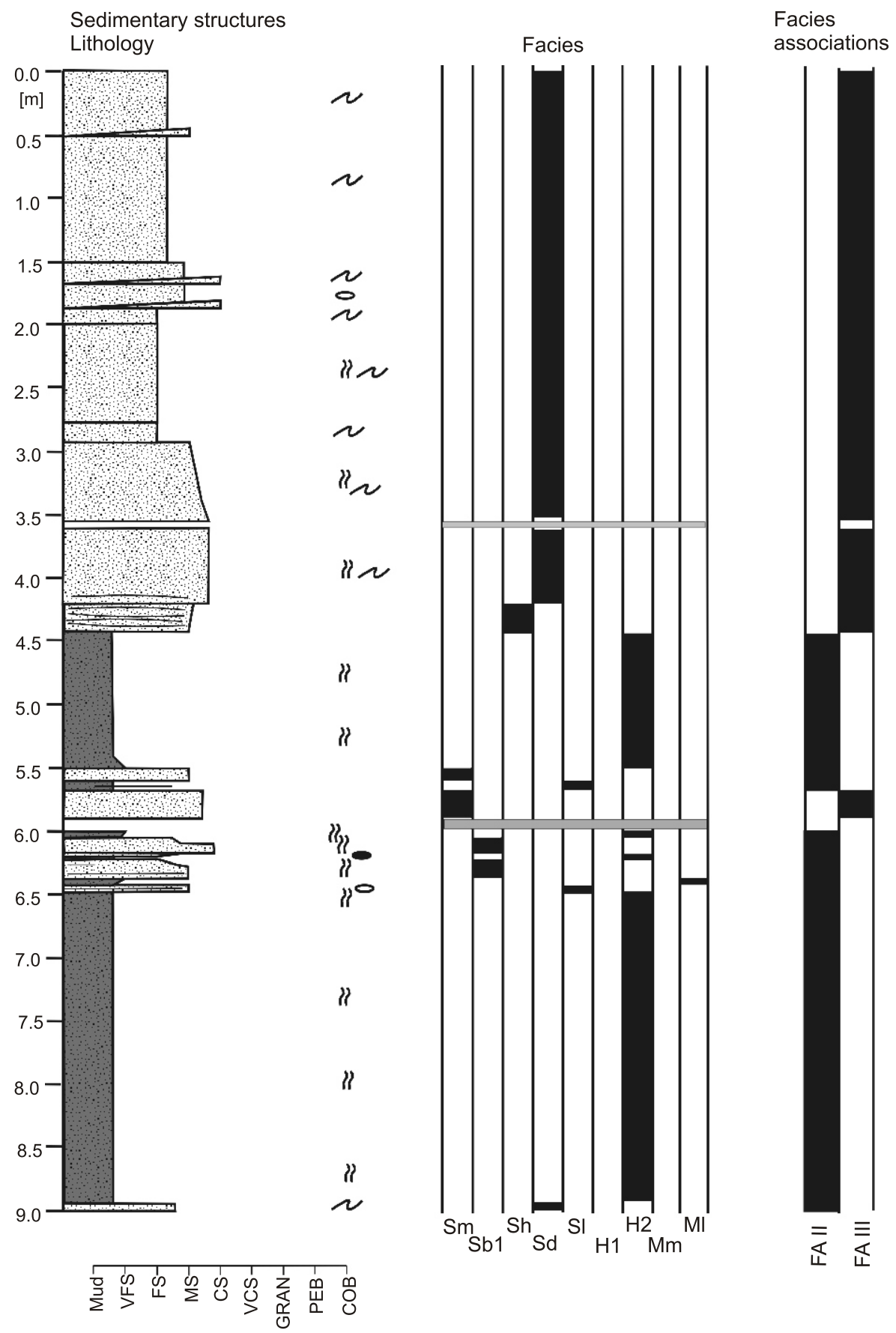

Fig. 8. Sedimentological core logs of the Nikolčice Formation from borehole Hustopeče 101

The logs show the stratigraphic distribution of sedimentary facies (letter code as in Table 1) and distinction of facies associations (FA II, III); for other explanations see Figure 5

monly composed of sub-association FA IIIb, which is typified by an important occurrence of lithofacies Sd and Sh.

Interpretation: ripple cross-lamination $(\mathrm{Sr})$ and cross-stratification $(\mathrm{Sp})$ reveal a lower flow regime and migration of ripples/dunes along the bottom. Common bioturbation (Sb) (ichnofacies Skolithos and Cruziana) reflects both a character- istic (unconsolidated, noncohesive) substrate and suitable conditions for bottom colonisation (time, nutrients). Subfacies Sb1 and $\mathrm{Sb} 2$ differ mostly by sorting, which may have been connected with variation in sediment input (grain size, velocity, amount). Planar lamination (SI) points to deposition from an upper flow regime. A low inclination of lamination is a common re- 
sult of beach processes (swash/backwash) (Clifton, 2006). Wavy deformation of the lamination (Sd) and hummocky cross-stratification (Sh) reflect a combined flow regime and are commonly connected with storm action. Massive/structureless fabric (Sm) can be explained by post-depositional (both physically and biologically) obliteration of primary structures.

The range of stratification types and the lack of mudstone indicate deposition of FA III in a perennially wave-worked shoreface and foreshore environment (Clifton, 1981, 2006; Hampson, 2000). Sub-association FA Illa represents the foreshore and FA IIIb the shoreface. Middle shoreface deposits with a prevalence of storm structures and upper shoreface deposits with a significant role of cross- and planar-stratification can be locally identified. Middle shoreface deposits are highly variable in terms of sedimentary structures and textures (Hunter et al., 1979). Fine- to medium-grained clean sands, with minimal amounts of silt, low-angle planar laminae, ripple and trough cross-laminae are typical (Campbell, 1971; Reinson, 1984). The relatively rare evidence of structures originated from dune migration may be connected with the dominance of fine-grained sand. A dominance of planar and low inclined stratification is common in such material in nearshore deposits under high energy conditions (Clifton, 2006). The low occurrence of facies $\mathrm{Sg}$ or Sgl (which alternate with facies $\mathrm{SI}, \mathrm{Sr}$ ) points to the limited role of coarse-grained nearshore deposits. These deposits are thought to represent a mixed sand-gravel foreshore system dominated by moderate-energy to high-energy waves (Massari and Parea, 1988; Bluck, 1999; Leszczyński and Nemec, 2015).

\section{FACIES ASSOCIATION IV}

FA IV was recognized in three boreholes and represents $8.6 \%$ of the logged cores. FA IV is dominantly formed by lithofacies Sg1, SI, Sd, Gm and Gi, rarely Sd or SI. Inclined bedding (dip generally at 15 to $25^{\circ}$ ) is typical. The minimum thickness of FA IV in cores exceeds $>2 \mathrm{~m}$ (top unpreserved); however, the thickness of sets or beds of individual facies is mostly $<20 \mathrm{~cm}$. Synsedimentary deformation structures are common. FA IV represents the coarsest deposits of the NF.

Interpretation: facies $\mathrm{Gi}$ and $\mathrm{Gm}$ are interpreted as gravity flow (debris flow) deposits. Facies Sg1 is interpreted as deposits of more turbulent water-laden gravity flows (high-density turbidity currents).

Inclined bedding, deposits of gravity flows, low thickness of sets or beds of individual facies, common synsedimentary deformation structures, all point to rapid deposition on a slope. FA IV overlies deposits of FA III or FA I. For these reasons FA IV is interpreted as deposits of littoral bars, possibly coastal spit and/or spit platform (cf. Nielsen et al., 1988; Nielsen and Johannessen, 2009; Linhorst et al., 2010; Leszczyński and Nemec, 2015).

Although cores with the occurrence of FA IV were relative rare and thin, the monotonous blocky shape of the wireline log (with relative low values of gamma and $\mathrm{sp}$ ) is typical of these deposits. The thickness of the NF deposits with a blocky shape of the log is 20 to $30 \mathrm{~m}$. The spatially restricted occurrence is typical of littoral bars.

\section{PEBBLE ANALYSES}

Conglomerates were relatively rare in the cores studied. The largest recognized pebble was about $3 \mathrm{~cm}$ across, though pebbles mostly reached about $1 \mathrm{~cm}$. The matrix is formed by fine- to medium-grained arkosic sandstone. Conglomerates can be partly $(8.2 \%)$ classified as monomict/quartzose, where the content of quartz pebbles is $>90 \%$. Quartz pebbles dominate in the great majority of the samples studied and their content varied between 30.7 to $100 \%$.

The rounding of quartz pebbles varies greatly. Rounded to subrounded pebbles seem to dominate in the majority of samples; however, subangular or even angular ones have been also recognized. The roundness index varies between 0.15 and 0.6. Quartz pebbles reveal a mostly spherical to bladed shape (sphericity index between 0.4 and 0.8 ). The quartz is milky, whitish, light or smoky grey, light rose, yellowish or brownish in colour. Dark quartzes were very rare. Quartzes typically represent the largest pebbles when their size varies between 5 and $30 \mathrm{~mm}$.

The majority of conglomerates analysed (91.8\%) was polymict, with the content of unstable rock pebbles of over $10 \%$. Cherts represent the second most common pebble componenta when their content varies between 0 and $38.5 \%$, but mostly it is $>10 \%$. Several colour varieties (dark grey, greyish brown) of cherts were observed. A dark and lustrous surface is typical. These pebbles are smaller than the quartz ones and reach a maximum of $2 \mathrm{~cm}$. They reveal a mostly spherical or bladed shape and are mostly well-rounded to rounded. Subangular to angular ones are rare. The roundness index varies between 0.25 and 0.6 .

Pebbles of metamorphic rocks are the most common ones among the rest of the rock pebbles and their content locally reaches $10-20 \%$. The content of gneisses (biotitic orthogneisses, paragneisses) in one sample reaches $30.9 \%$. The gneiss pebbles have a mostly discoidal and bladed shapes. The roundness index varies between 0.25 and 0.6 . The size of these pebbles can reach up to $1.6 \mathrm{~cm}$. Less common $(0.0-3.3 \%)$ were phyllites or quartzites and very rare granulites. Their size sometime reaches up to $1.5 \mathrm{~cm}$.

The content of magmatic rocks is even lower (0-2.9\%). They are represented by quartz porphyries, aplites and granitic rocks. The size of magmatic pebbles vary between 0.3 and $2 \mathrm{~cm}$. The roundness of these pebbles varies greatly (wellrounded to sub-angular). They comprise mostly spherical or bladed shapes.

Pebbles of sedimentary rocks were also recognized in some samples. Their content varies between 0 and $15.5 \%$. They are mostly formed by various kinds of sandstone (arkoses, wackes, quartzose sandstones). The rounding of sandstone pebbles varies; subangular pebbles slightly prevail. The sandstone pebbles are mostly discoidal; their size can reach up to $1.5 \mathrm{~cm}$. Siltstones, claystones or shales were less common. Their content only rarely reaches up to $4.5 \%$. The pebbles of these rocks were mostly angular to subangular; however, rounded ones were also identified. They are of predominantly discoidal shape and reach a maximum of $2 \mathrm{~cm}$ in size.

The pebble composition of the studied conglomerates is shown in Figure 9.

\section{PETROGRAPHY OF SANDSTONES}

The sandstones are mostly fine to medium but rarely coarse-grained, with varied contents of scattered granules or small pebbles, and micaceous. The values of skewness (Sk; Trask, 1932) range between 0.64 and $1.18 \varphi$ (average $0.9 \varphi$ ), negative skewness only slightly predominates $(52.6 \%)$. The value of sorting (So; Trask, 1932) varies greatly between 1.4 and $3.1 \varphi$ (average $1.6 \varphi$ ); however, a large majority $(72.2 \%)$ is between 1.4 an $1.6 \varphi$. 


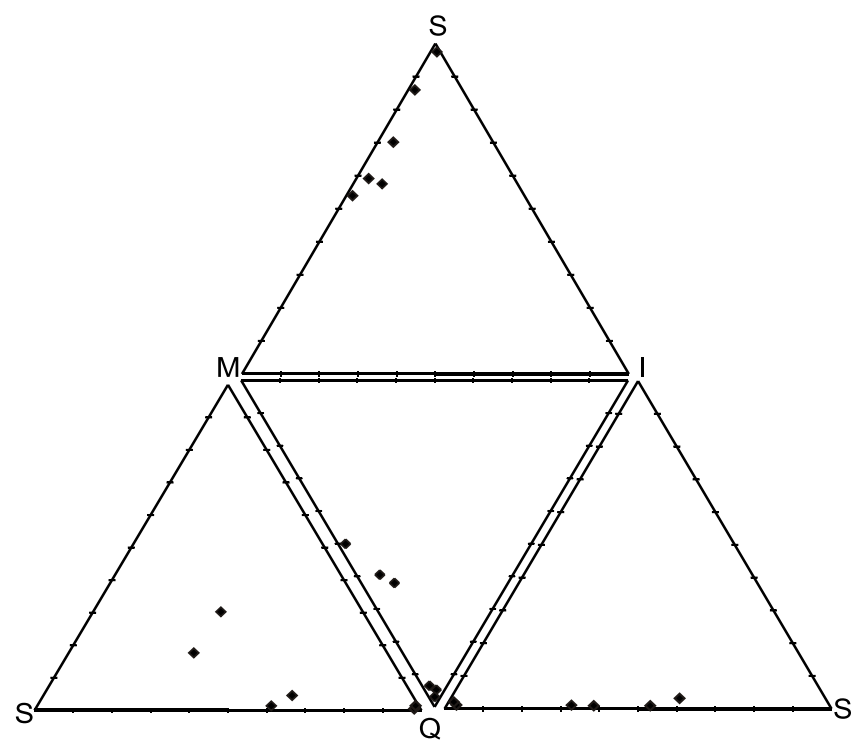

Fig. 9. Ternary diagrams illustrating composition of pebbles of the conglomerates studied

$S$ - sedimentary rocks, I-igneous rocks,

$\mathrm{M}$ - metamorphic rocks, $\mathrm{Q}$ - quartz

Sandstones contain a prevalent amount of quartz, which is more commonly mono- and less frequently polycrystalline and subangular. Stable grains are also formed in small amounts by chert and quartzite. K-feldspars (mostly orthoclase) commonly dominate over plagioclases (albite, oligoclase, andesine). Feldpars are locally kaolinised. The content of rock fragments reaches usually only a few percent; however, it varies greatly in individual samples. Grains of quartzite and porphyre/porphyrite dominate in the rock spectra. Grains of granitic rocks, aplites, pegmatites, chloritic and graphitic phyllites, dark mudstones and sandstones are less common. Micas (some deformed) are relatively common. Biotite prevails over muscovite in some samples.

Angular and subangular grains prevail over rounded ones in general. Relatively more rounded are grains of quartzes and granitic rocks. The grains of these rocks are typically slightly larger than other clasts. The content of small coal fragments or coalified plant detritus varies greatly. Pyrite commonly accompanies these fragments.

The matrix is formed by a mixture of clay and silt; however, carbonates (dolomite) commonly replace detrital grains and represent the prevalent matrix. Dolomitization is associated with post-depositional processes and is mostly identified in relatively highly pervious/porous sandstones.

On a Q-F-L (Fig. 10) discrimination diagram (Dickinson, 1985; Ingersoll, 1990), the samples clearly reflect sources from the continental block.

\section{HEAVY MINERALS}

Heavy minerals are sensitive indicators of provenance, weathering, transport, deposition and diagenesis (Morton and Hallsworth, 1994). Heavy mineral ratios ATi (100 x apatite count/total apatite plus tourmaline), GZi (100 x garnet count/total garnet plus zircon), RuZi (100 x rutile count/total rutile plus zircon) (see Morton and Hallsworth, 1999) and the ZTR (total zircon plus tourmaline plus rutile) index have been evaluated,

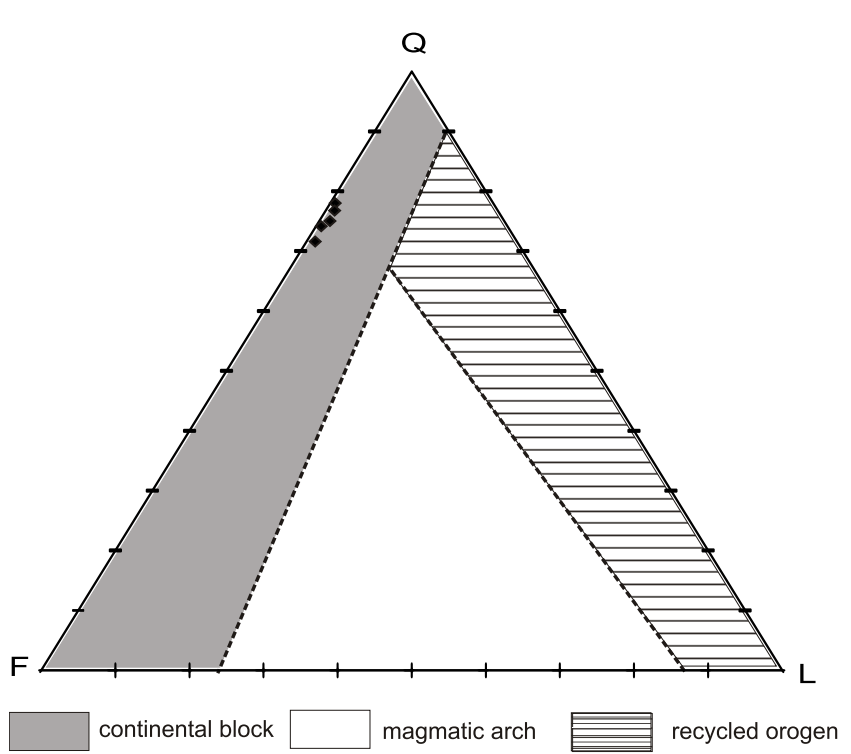

Fig. 10. Discrimination ternary diagram (according to Dickinson, 1985; Ingersoll, 1990) of the sandstones studied

$\mathrm{Q}$ - monocrystalline + polycrystalline quartz, $\mathrm{F}$ - plagioclase + $\mathrm{K}$-feldspar, $\mathrm{L}$ - lithic fragments

together with a study of heavy mineral spectra. ATi, GZi and RuZi provide a solid reflection of the source rock characteristics, being comparatively immune to alteration (Morton and Hallsworth, 1994). The ZTR index is widely accepted as a criterion for the mineralogical "maturity" of heavy mineral assemblages (Hubert, 1962; Morton and Hallsworth, 1994) in the case of derivation from a similar source. Differences in the heavy mineral assemblages can also be used to indicate successive stages in provenance evolution, the tectonic history and resulting depositional processes, in particular if supported by study of individual minerals. Garnet, zircon, and rutile were selected for such detailed studies.

\section{HEAVY MINERAL ASSEMBLAGES}

Garnet dominates in the absolute majority (87.6\%) of samples and its content varies between 3.1 and $94.5 \%$ (average $72.8 \%$, mostly $>60 \%$ ). Zircon dominates in the rest of the samples $(12.6 \%)$ and its content generally varies between 3.0 and $86.6 \%$ (average 9.4\%). Rutile (0.0-16.2\%), anatase (0.0-8.9\%), tourmaline (0.0-4.5\%), apatite $(0.0-22.2 \%)$ and titanite $(0.0-4.4 \%)$ represent further commonly identified heavy minerals. The presence of staurolite, chloritoid, pyroxene, amphibole, epidote, disthene, monazite or sillimanite was rare. The heavy mineral assemblages are mostly (45.7\%) described as garnet-zircon ones or garnet (32.9\%). Less common were zircon-garnet or zircon (10\% in both cases). Garnet-zircon-rutile was rare (1.4\%). The value of the ZTR ranges between 3.5 and 89.0 (average 22.1, standard deviation 17.4). Zircon always dominates within these very stable minerals. The ATi ratio ranges from 0.21 to 1 (average 0.71 , standard deviation 0.22 ), GZi varies between 0.04 and 0.98 (average 0.79 , standard deviation 0.18 ) and RuZi ranges from 0.02 to 0.44 (average 0.12 , standard deviation 0.09). 


\section{RUTILE}

The concentrations of the main diagnostic elements ( $\mathrm{Fe}$, $\mathrm{Nb}, \mathrm{Cr}$ and $\mathrm{Zr}$ ) vary significantly in the samples studied. The content of $\mathrm{Fe}$ shows that all rutiles evaluated originated from metamorphic rocks. The concentration of $\mathrm{Nb}$ ranges between 370 and 4150 ppm (average 1813 ppm), the concentration of $\mathrm{Cr}$ varies between 50 and 6690 ppm (average 1036 ppm), the concentrations of $Z r$ ranges between 100 and 6490 ppm (average $2741 \mathrm{ppm}$ ) and most (73.7\%) of log $\mathrm{Cr} / \mathrm{Nb}$ values are negative. A discrimination plot of $\mathrm{Cr}$ vs. $\mathrm{Nb}$ is shown in Figure 11. The dominant $(68.4 \%)$ origin of rutile was from metapelites (mica-schists, paragneisses, felsitic granulites) and additionally (15\%) from metamafic rocks (eclogites, basic granulites), according to the grouping by Zack et al. (2004a, b) or Triebold et al. (2007). The rest of the results (out of the diagnostic fields) may originate from amphibolites according to the grouping by Zack et al. (2004a, b) or Triebold et al. (2007). Newly published diagnostic criteria (Triebold et al., 2012) further suggest a provenace mainly from metapelites $(66.7 \%)$ over metamafic sources $(23.8 \%)$.

Zr-in-rutile thermometry was applied to metapelitic rutiles only (see Zack et al., 2004 a, b; Meinhold et al., 2008). The results indicate that most metapelitic rutile originates from granulite metamorphic facies or possibly from amphibolite/eclogite facies. Sources from such a highly metamorphosed crystalline rocks indirectly points to an advanced stage of erosion of the source area.

\section{ZIRCON}

The evaluation of the source rock, the role of recycling and the erosion rate may be inferred from zircon studies (Poldervaart, 1950; Mader, 1980; Winter, 1981; Lihou and Mange-Rajetzky, 1996).

Euhedral zircons represent $25.8 \%$, subhedral zircons form $31.3 \%$ and rounded to subrounded ones $42.9 \%$ of the zircon spectra of the NF. Colourless zircons forming $47.4 \%$ dominate over zircons with a pale colour (42.5\%), brown ones $(9.5 \%)$ and

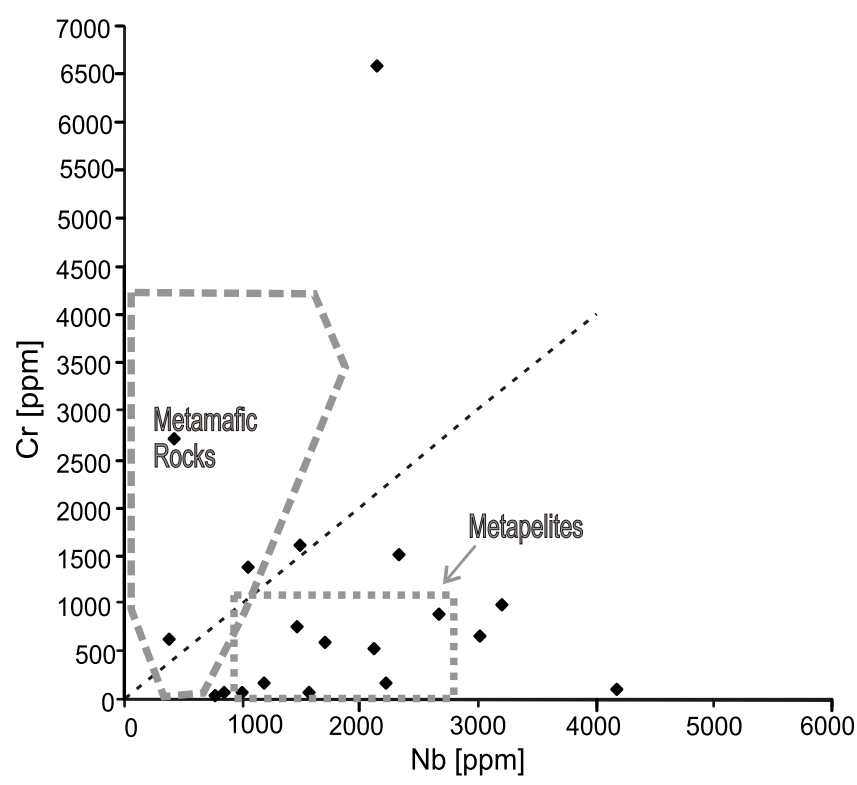

Fig. 11. Discrimination plot of $\mathrm{Cr}$ vs. $\mathrm{Nb}$ of rutiles investigated pink zircons $(0.7 \%)$. The proportion of zoned zircons is high $(38.2 \%)$, zircons with older cores were also relatively common $(12.4 \%)$. Inclusions were recognized in $98.2 \%$ of the grains studied.

Elongation (the relationship between the length and width of crystals) was used as an indicator for possible host rocks, cooling rate or transport duration (Poldervaart, 1950; Hoppe, 1966; Zimmerle, 1979; Finger and Haunschmid, 1988). The average value of elongation of the zircons studied is 2.2 and the distribution of elongation is shown in Figure 12A. Zircons with elongation $>2.0$ are more common $(52.9 \%)$ than zircons with elongation $<2.0(42 \%)$. Zircons with an elongation of $>3$ represent $9.5 \%$. Such zircons are supposed to reflect a volcanic origin and/or limited transport (Zimmerle, 1979). The maximum elongation was 4.2; however, broken prisms of columnar crystals of zircon were relatively common. Zircon intergrowths were as common as numerous crystal fractures.

Evaluation of zircon typology according to Pupin (1980, 1985 ) is based on the evaluation of external zircon faces (both pyramids and prisms). This method assumes that the parent magma (especially the aluminium and alkali content and the crystallisation temperature) show a correlation with the produced zircon subtype. A standard designation was proposed for 64 zircon subtypes (Pupin, 1980, 1985). Study of zircon typology points to the hybrid character of the parent magma. In the

\section{A}

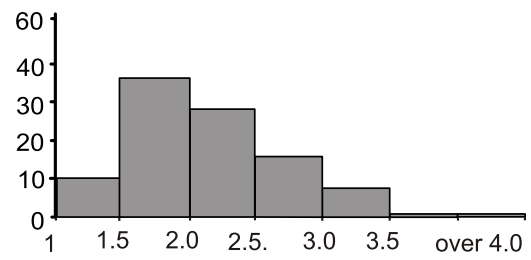

B

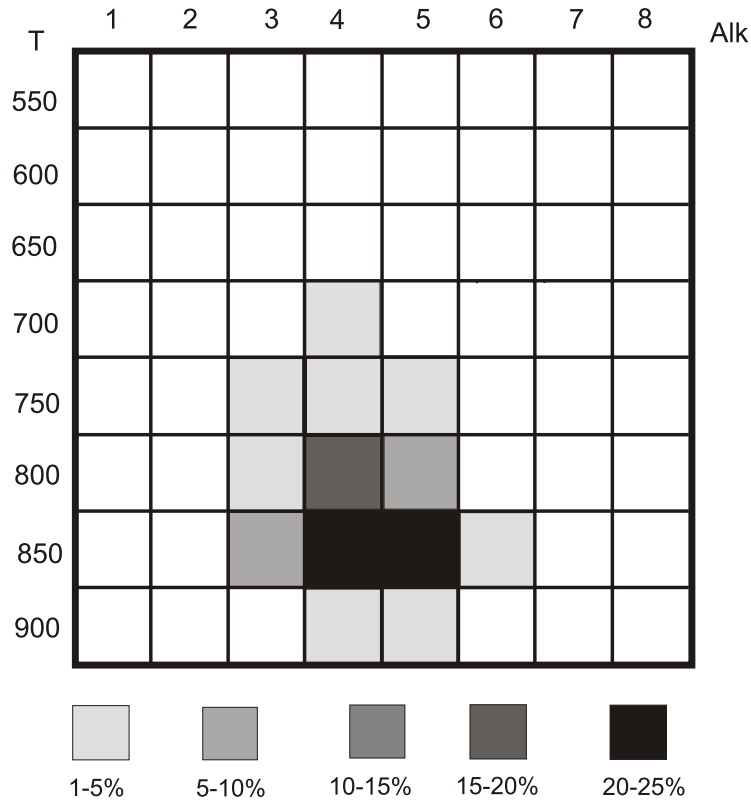

Fig. 12. Diagrams of the zircons studied: A - histogram of zircon elongation, B - typology of the zircons in the diagram of Pupin (Pupin, 1980) 
case studied, a relative broad spectrum of subtypes has been recognized. The most common were the typological subtypes S23 (26.4\%), S24 (25.2\%) and S18 (13.2\%). Further subtypes i.e. S7, S9, S12, S13, S14, S17, S19, S20, S21, S22, S 25, J3 and $\mathrm{J} 4$ were less common. The distribution and abundances of zircon subtypes in the typological diagram of Pupin (1980) is shown in Figure 12B. The diagram shows an almost symmetrical occurrence of crystals with flat [101] and steep pyramids [211] and a strong predominance of the prism form [100] over the form [110].

\section{GARNET}

The chemistry of detrital garnet is widely used for the more detailed determination of source rocks (Morton, 1984). Several garnet types were identified in the samples studied. Table 2
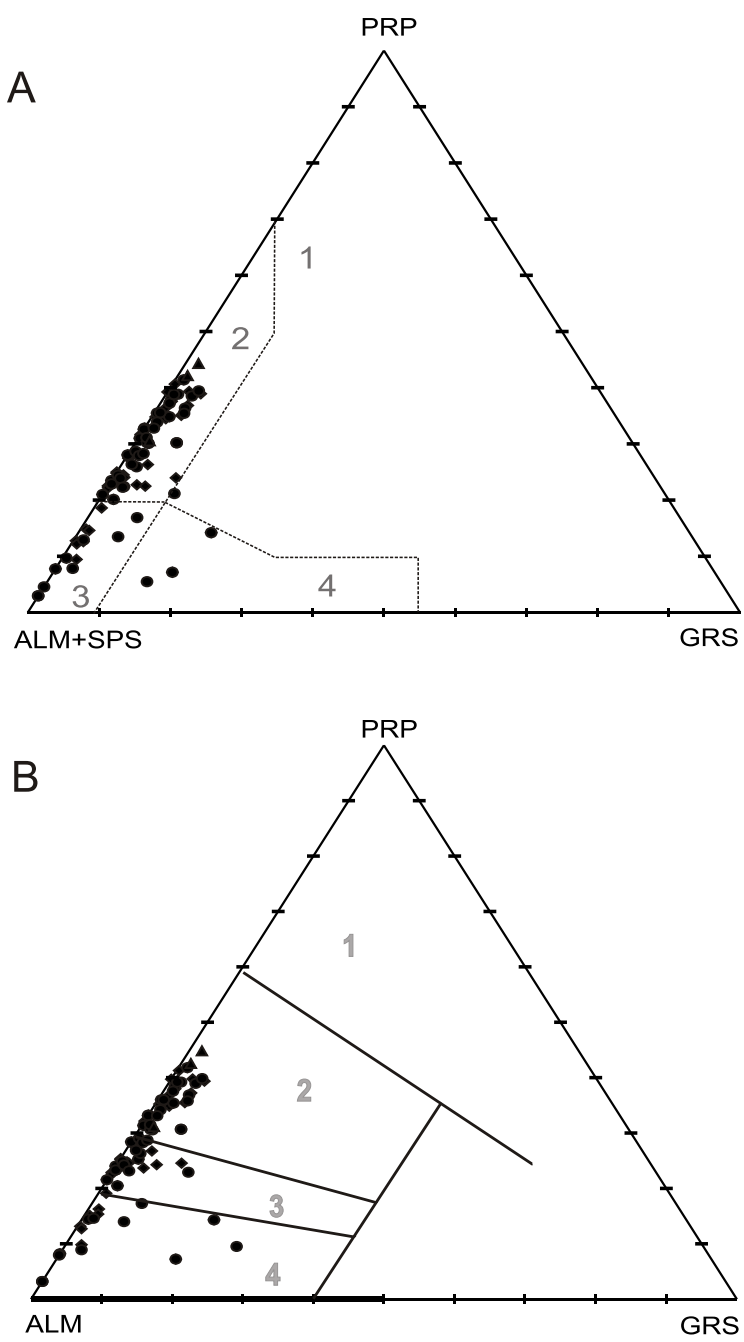

Fig. 13. Ternary diagrams of the chemistry of detrital garnets (ALM - almandine, GRS - grossular, PRP - pyrope, SPS - spessartine) shows the relative abundance of these garnet types and reveals the strong dominance of almandines. Moreover one type i.e. pyrop-almandines (ALM 55-83\%, PRP 12-44\%, GRS 0-9\%, SPS $1-8 \%$, AND $1-2 \%)$ strongly predominates $(82.5 \%)$ in the garnet spectra.

Several ternary discrimination diagrams were utilized for more detailed identification of the primary source of garnet (Fig. 13). The PRP-ALM+SPS-GRS diagram (Mange and Morton, 2007 ) in Figure 10A reflects the dominant $(76.7 \%)$ of garnets from high-grade granulite facies metasedimentary rocks and intermediate felsic igneous rocks; significantly less common $(19.5 \%)$ are garnets from intermediate to felsic igneous rocks and garnets from amphibolite-facies metasedimentary rocks are rare $(3.8 \%)$. The PRP-ALM-GRS diagram (Aubrecht et al., $2009)$ in Figure 13B indicates the dominant (46.9\%) primary source of garnets derived from eclogite- and granulite facies rocks and also (31.6\%) garnets derived from gneisses metamorphosed under pressure and temperature conditions transi-

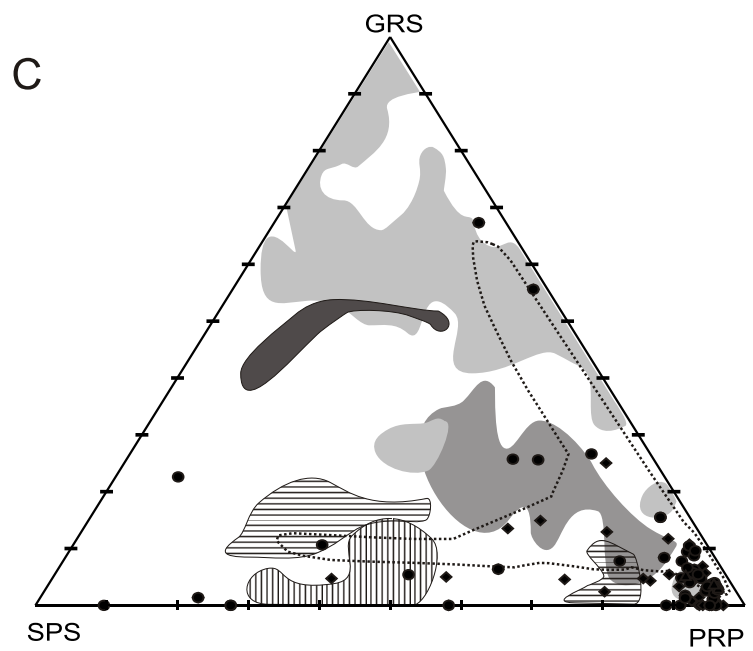

Moravian Zone

Moldanubicum

Svratka Crystalline Complex

granites of the Brno Massif

migmatites of the Brno Massif

younger part

of the Moravian-Silesian Paleozoic/Culmian

A - discrimination diagram according to Mange and Morton (2007) (1 - pyroxenes and peridotites, 2 - high-grade granulite facies metasedimentary rocks and intermediate felsic igneous rocks, 3 - intermediate to felsic igneous rocks, 4 - amphibolite facies metasedimentary rocks); B - discrimination diagram according to Aubrecht et al. (2009) (1 - pyroxenes and peridotites, 2 - felsic and intermediate granulites, 3 - gneisses and amphibolites metamorphosed under pressure and temperature conditions transitional to granulite and amphibolite facies metamorphism, 4 - gneisses metamorphosed under amphibolite facies conditions); C - ternary diagram of the chemistry of detrital garnets in comparison with possible source areas; data from source rocks according to Otava et al. (2000), Čopjaková et al. (2002, 2005), Čopjaková (2007) and Buriánek et al. (2012) 
T a b le 2 dominance of a polymict composition with some role of monomict/quartzose one as well as the dominance of monotonous (garnet-dominated) heavy mineral assemblage with in places significant role of very stable minerals (zircon dominated) can be inferred. These results can also suggest varied source area morphology and/or climatic variations (less and more humid conditions).

The relatively monotonous heavy mineral spectra, varied and commonly high values of ZTR index, low and varied content of less stable minerals (apatite, pyroxene, amphibole, staurolite), all reflect intensively weathered source crystalline rocks, with a significant role of garnet-bearing mica schist and also magmatic rocks. High values of the ZTR index may also suggest relatively more redeposition from an older sedimentary cover, which is also suggested by clasts of sedimentary rocks in both sandstones and conglomerates. Faupl (1975) described similar heavy mineral assemblages (dominance of garnet, apatite and zircon) for the Grestener Klippen-unit in both Upper and Lower Austria.

The garnet and rutile composition suggest proveALM - almandine, GRS - grossular, PRP - pyrope, SPS - spessartine AND - andradite, UVA - uvarovite

tional to granulite- and amphibolite-facies metamorphism. Garnets from amphibolite-facies rocks (mostly amphibolites less commonly gneisses) are less common (21.5\%).

The strong dominance of pyrop-almandines (close to $80 \%$ ) is typical of Permo-Carboniferous rocks of the Boskovice Basin (Nehyba et al., 2012). A significant similarity can be seen with the garnet spectra from the underlying Gresten Formation (Nehyba and Opletal, 2016; Fig. 14).

\section{INTERPRETATION OF RESULTS OF THE PROVENANCE ANALYSES}

The results point to a primary source from an intensively weathered crystalline source and also some role of redeposition from an older sedimentary cover. Variations in sorting, grain shape, roundness and mica content, all point to different lengths of transport and the role of redeposition. Similarly, the

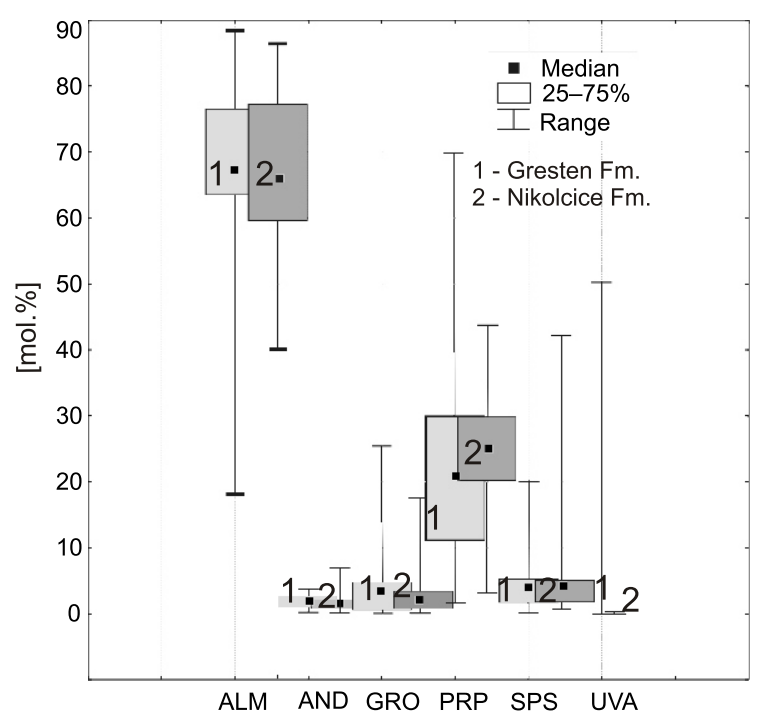

Fig. 14. Comparison of garnet composition of the Nikolčice and Gresten formations

For other explanations see Table 2 nance from high-grade metamorphosed crystalline rocks (granulite-, eclogite- and amphibolite metamorphic facies) (Force, 1980; von Eynatten and Gaupp, 1999). Zircon studies confirmed primary sources of acidic and intermediate magmatic rocks (especially aluminous granitoids) and we can speculate about the role of the S-type granitoids in the source area (cf. Sturm, 2010). The typological spectrum of the zircons studied differs from published data from granitoids of the Moldanubian Pluton (Finger and Haunschmid, 1988; Sturm, 2010), and some similarities can be found with gneisses of the Moldanubian Zone (Sturm, 2010). A GRS-SPS-PRP diagram (Fig. 13C) allows comparison with possible source rocks along the eastern margin of the Bohemian Massif (Otava et al., 2000; Čopjaková et al., 2002, 2005; Čopjaková, 2007; Buriánek et al., 2012). Some garnets from the NF may be compared with those from the Moravian Zone, the Moldanubicum, or the Svratka Crystalline Complex of the Bohemian Massif. The results are centred in the pyrope corner with a distinct lateral distribution in both the PRP-GRS and PRP-SPS lines. A distribution in such lines was recognized for the Myslejovice Fm. of Moravian-Silesian Paleozoic (Culmian) deposits (Otava et al., 2000).

Data can be compared, moreover, with results from the Jurassic deposits of the Western Carpathians (Aubrecht and Méres, 2000; Aubrecht et al., 2009) and the Polish Platform (Méres et al., 2012). Although high-pyrope garnets are known to be abundant in Mesozoic deposits of the Outer Western Carpathians, the distribution of the garnet types and comparison of discriminant diagrams shows only slight similarity to the data from the NF.

The source area of intensively weathered crystalline rocks is located on the eastern margins of the Bohemian Massif, where some possible recycled sources, such as the Moravo-Silesian Paleozoic deposits (Hády-Říčka Fm. and Myslejovice Fm.) are also located. An important role of post-depositional changes of heavy mineral spectra (i.e. especially dissolution of less stable minerals - cf. Garzanti and Andò, 2007) is not indicated.

\section{DISCUSSION}

Provenance analyses show similarity in the source area of the deposits of the NF and the underlying Gresten Formation 
(GF). Deposits of the GF were mostly interpreted as fluvial deposits (Nehyba and Opletal, 2016). Identification of some differences in the provenance between these two formations is interesting for palaeogeographic reconstruction. The results in general point to the more important role of primary sources (metamorphic and magmatic rocks) and a lesser role of redeposition from older sedimentary rocks for the NF than for the GF. The composition of garnets of the NF is more uniform and reveals a higher proportion of garnets from gneisses, eclogite- and granulite facies rocks and a lower proportion of garnets from amphibolite-facies rocks, when compared to data from the GF. Zircon studies reveal the most significant differences between the GF and the NF. Zircons of the NF originate predominantly from plutonic rocks, with a significantly lower importance of volcanic or intrusive rocks compared to the GF. These observations probably indicate evolution in the erosional level in the source area/or differences in expansion of the provenance area. Lowering of the erosional level led to successive exhumation of the Variscan orogen of the eastern margins of the Bohemian Massif and erosion of its deeper/inner parts.

Several variations in the log shapes (Rider, 1986) of the NF deposits have been recognized within the area under study; however, detailed evaluation of the log shapes is influenced by the large differences in thickness of the formation. The start of deposition of the NF may be connected with a transgressive surface, above which a generally funnel shape (coarsening upwards) of the wireline logs has been recognized (Uhřice: 38a, $27,28,56$, Němčičky 5 , Nikolčice 6 and Hustopeče 101 boreholes). The thickness of the NF in these boreholes varies greatly, being between $8 \mathrm{~m}$ and $81 \mathrm{~m}$. An upwards shallowing/coarsening succession typically reveals progradation. Such a repeating prograding succession terminated by a flooding surface is in the terminology of sequence stratigraphy described as a parasequence or parasequence set (Catuneanu et al., 2011). Evidence of several prograding parasequences, with thicknesses between a few metres and $\sim 20 \mathrm{~m}$, is common in these boreholes. The lower parts of these coarsening upward cycles were documented by several cores and are formed by deposits of FA I or FA II, whereas the upper parts were interpreted mostly as FA III, rarely as FA II.

Upward transitions to the irregularly blocky shape of the borehole logs can be followed in some boreholes (Uhřice: 27 , 28 and Němčičky 5). The deposits of the upper parts of these prograding cycles studied were interpreted mostly as FA III, rarely as FA II.

Such a situation reveals normal regression, when a significant sedimentary input into the basin followed sea level rise or stillstand. This part of the succession of the NF may be linked with a highstand systems tract. Prograding cycles can in some cases be interpreted as R cycles (Zecchin, 2007) and gradual transition from progradation to aggradation may be supposed. The restricted preservation of such cycles, together with significant variations in the thickness of the cycles, the number of cycles and the total thickness of the NF may be evidence of the varied morphology of the basin margin/nearshore environment and/or an areally restricted input of material into the basin (river delta). This interpretation may be also supported by the restricted occurrence of FA IV.
The highest thickness of the NF was recognized in the borehole Uhrice 11 (i.e. $115 \mathrm{~m}$ ). Here the lower part of the succession with a prograding funnel-shaped wireline log is followed by the irregularly blocky middle part and is terminated by an irregular bell shape of the log, which reveals a retrograding pattern (both SP and RAG logs). A similar bell shape of the log was recognized in the upper part of the NF in the Uhrice: 28, 29, 43, Hustopeče 101, Němčičky 5 and Nikolčice 6 boreholes. Such a log shape is commonly connected with the dominance of formation of accommodation space over sediment input and with a relative sea level rise. The maximum regressive surface can be located where the lithological trend changes from prograding upwards to retrograding upward (Embry and Johannessen, 1993). This situation could indicate the existence of several depositional sequences within the NF.

\section{CONCLUSIONS}

A sedimentological study of the clastic deposits of the Nikolčice Formation (Middle Jurassic) was performed on deep subsurface cores from 14 boreholes. Altogether 17 lithofacies and 4 lithofacies associations have been identified. Depositional environments of offshore, transitional zone, shoreface, foreshore and littoral sand bars have been interpreted; however, shoreface and foreshore deposits significantly dominate in the cores studied. Upper and lower shoreface have been identified in detail in some cases.

Deposits of the Nikolčice Formation varied greatly lithologically. Conglomerates can be mostly classified as polymict, whereas monomict/quartzose ones are rare.

The primary source of deposits of the Nikolčice Formation is suggested to lie within crystalline units along the eastern margins of the Bohemian Massif. An important role was played by acidic and intermediate plutonites and highly metamorphosed metasedimentary rocks (granulite and amphibolite metamorphic facies), which points to an advanced stage of erosion of the source area. The role of volcanic and intrusive rocks was small. Some role was also played by recycled material from the older sedimentary cover. The source of the recycled material is located in the Moravo-Silesian Paleozoic deposits (the Lišeň Formation, the Myslejovice Formation).

A significant similarity between the source area of the Nikolčice Formation and the underlying Gresten Formation was recognized. Identified differences in the source areas of these two formations can be mainly explained by varied erosional levels due to successive exhumation of the orogen and possibly also by an expansion of the source area. These results can be used in palaeogeographic reconstructions of the Jurassic drainage system and extent of the flooding of the eastern margin of the Bohemian Massif.

Acknowledgements. The authors would like to thank MND a.s. for providing the primary data and material support. We are obliged to R. Aubrecht, M. Krobicki, T.M. Peryt, G. Pieńkowski and an unknown reviewer for their stimulating comments and thorough reviews. 


\section{REFERENCES}

Adámek, J., 1986. Geologické poznatky o stavbě mesozoika v úseku Jih jv. svahu Českého masivu (in Czech). Zemní Plyn a Nafta, 31, 4: 453-484.

Adámek, J., 2002. Regionálně-geologické zhodnocení sedimentů jury v oblasti jihovýchodních svahů Českého masívu (in Czech). Geologické Výzkumy na Moravě a ve Slezsku v Roce 2001: 9-11.

Adámek, J., 2005. The Jurassic floor of the Bohemian Massif in Moravia - geology and palaeogeography. Bulletin of Geosciences, 80: 291-305.

Anonymous, 1992. Outline of sedimentation, tectonic framework and hydrocarbon occurrence in Eastern Lower Austria. Austrian Journal of Earth Sciences, 85: 5-96.

Aubrecht, R., Méres, Š., 2000. Exotic detrital pyrope-almandine garnets in the Jurassic sediments of the Pieniny Klippen Belt and Tatric Zone: where did they come from? Mineralia Slovaca, 32: 17-28.

Aubrecht, R., Méres, Š., Sýkora, M., Mikus, T., 2009. Provenance of the detrital garnets and spinels from the Albian sediments of the Czorsztyn Unit (Pieniny Klippen Belt, Western Carpathians, Slovakia). Geologica Carpathica, 60: 463-483.

Bluck, B.J., 1999. Clast assembling, bed-forms and structure in gravel beaches. Transactions of the Royal Society Edinburgh, Earth Sciences, 89: 291-323.

Buriánek, D., Tomanová Petrová, P., Otava, J., 2012. Kde je zdroj klastických sedimentů miocénu Brněnska? (in Czech). Acta Musei Moraviae, Scientae Geologicae, 97: 153-166.

Campbell, C.V., 1971. Depositional model - Upper Cretaceous Gallup beach shoreline, Ship Rock area, Northwestern New Mexico. Journal of Sedimentary Petrology, 41: 395-405.

Catuneanu, O., Galloway, W.E., Kendall, Ch.G.St.C., Miall, A.D., Posamentier, H.W., Strasser, A., Tucker, M.E., 2011. Sequence stratigraphy: methodology and nomenclature. Newsletters on Stratigraphy, 44: 173-245.

Cizek, P., Tomek, C., 1991. Large-scaled thin skinned tectonics in the eastern boundary of the Bohemian Massif. Tectonics, 10: 273-286.

Clifton, H.E., 1981. Progradational sequences in Miocene shoreline deposits, southeastern Caliente Range, California. Journal of Sedimentary Petrology, 51: 165-184.

Clifton, H.E., 2006. A reexamination of facies models for clastic shorelines. Facies Models revisited. SEPM Special Publication, 84: 293-338.

Čopjaková, R., 2007. The reflection of provenance changes in the psefitic and psamitic sedimentary fraction of the Myslejovice Formation (heavy mineral analysis) (in Czech). Ph.D. thesis, Masaryk University, Brno.

Čopjaková, R, Sulovský, P., Otava, J., 2002. Comparison of the chemistry of detritic pyrope-almandine garnets of the Luleč Conglomerates with the chemistry of granulite garnets from the Czech Massif (in Czech). Geologické Výzkumy na Moravě a ve Slezsku v Roce 2001, Brno: 44-47.

Čopjaková, R., Sulovský, P., Paterson, B.A., 2005. Major and trace elements in pyrope-almandine garnets as sediment provenance indicators of the Lower Carboniferous Culm sediments, Drahany Uplands, Bohemian Massif. Lithos, 82: 51-70.

Dickinson, W.R., 1985. Interpreting provenance relations from detrital modes of sandstones. In: Provenance of Arenites (ed. G.G. Zuffa): 333-361. D. Reidel Publication Co.

Embry, A.F., Johannessen, E.P., 1993. T-R sequence stratigraphy, facies analysis and reservoir distribution in the uppermost Triassic-Lower Jurassic succession, western Sverdrup Basin, Arctic Canada. NPF Special Publication, 2: 121-146.

Eliáš, M., Wessely, G., 1990. The autochthonous Mesozoic on the eastern flank of the Bohemian Massif: an object of mutual geological efforts between Austria and Czechoslovakia. In: Thirty Years of Geological Cooperation Between Austria and Czechoslovakia (eds. D. Minaříková and H. Lobitzer). GBA Vienna, ČGÚ Praha.
Faupl, P., 1975. Kristallinvorkommen und terrigene Sedimentgesteine in der Grestener Klippenzone (Lias-Neokom) von Ober- und Niederösterreich. Jahrbuch der Geologischen Bundesanstalt, 118: $1-74$.

Finger, F., Haunschmid, B., 1988. Die mikroskopische Untersuchung der akzessorischen Zirkone als Methode zur Klärung der Intrusionsfolge in Granitgebieten - eine Studie im nordöstlichen oberösterreichischen Moldanubikum. Jahrbuch der Geologischen Bundesanstalt, 131: 255-266.

Force, E.R., 1980. The provenance of rutile. Journal of Sedimentary Research, 50: 485-488.

Garzanti, E., Andò, S., 2007. Heavy mineral concentration in modern sands: implications for provenance interpretation. Developments in Sedimentology, 58: 517-545.

Hampson, G.J., 2000. Discontinuity surfaces, clinoforms, and facies architecture in a wave-dominated, shoreface-shelf parasequence. Journal of Sedimentary Research, 70: 325-340.

Hoppe, G., 1966. Zirkone aus Granuliten. Berichte der Deutschen Gesellschaft für Geologische Wissenschaften, Reihe B. Mineralogie und Lagerstättenforschung, 11: 47-81.

Hubert, J.F., 1962. A zircon-tourmaline-rutile maturity index and the interdependence of the composition of heavy mineral assemblages with the gross composition and texture of sandstones. Journal of Sedimentary Petrology, 32: 440-450.

Hunter, R.E., Clifton, H.E., Phillips, R.L., 1979. Depositional processes, sedimentary structures and predicted vertical sequences in barred nearshore systems, northern Oregon coast. Journal of Sedimentary Petrology, 49: 711-726.

Ingersoll, R.V., 1990. Actualistic sandstone petrofacies: discriminating modern and ancient source rocks. Geology, 18: 733-736.

Jachowicz, M., Přichystal, A., 1997. Lower Cambrian sediments in deep boreholes in south Moravia. Czech Geological Survey Bulletin, 72: 329-332.

Kalvoda, J., Bábek, O., Fatka, O., Leichmann, J., Melichar, R., Nehyba, S., Špaček, P., 2008. Brunovistulian terrane (Bohemian Massif, Central Europe) from late Proterozoic to late Palaeozic: a review. International Journal of Earth Sciences, 97: 497-517.

Leszczyński, S., Nemec, W., 2015. Dynamic stratigraphy of composite peripheral unconformity in a foredeep basin. Sedimentology, 62: 645-680.

Lihou, J.C., Mange-Rajetzky, M.A., 1996. Provenance of the Sardona Flysch, eastern Swiss Alps: example of high-resolution heavy mineral analysis applied to an ultrastable assemblage. Sedimentary Geology, 105: 141-157.

Lindhorst, S., Fürstenau, J.H., Hass, Ch., Betzler, Ch., 2010 Anatomy and sedimentary model of a hooked spit (Sylt, southern North Sea). Sedimentology, 57: 935-955.

Mader, D., 1980. Weitergewachsene Zirkone im Buntsandstein der Westeifel. Der Aufschluss, 31: 163-170.

Mange, M.A., Morton, A.C., 2007. Geochemistry of heavy minerals. Developments in Sedimentology, 58: 345-391.

Massari, F., Parea, G.C., 1988. Progradational gravel beach sequences in a moderate- to high-energy, microtidal marine environment. Sedimentology, 35: 881-913.

Meinhold, G., Anders, B., Kostopoulos, D., Reischmann, T., 2008. Rutile chemistry and thermometry as provenance indicator: an example from Chios Island, Greece. Sedimentary Geology, 203: 98-111.

Méres, Š., Aubrecht, R., Gradiński, M., Sýkora, M., 2012. High (ultrahigh) pressure metamorphic terrane rocks as the source of the detrital garnets from the Middle Jurassic sands and sandstones of the Cracow Region (Cracow-Wieluń Upland, Poland). Acta Geologica Polonica, 62: 231-245.

Morton, A.C., 1984. Stability of detrital heavy minerals in Tertiary sandstones from the North Sea Basin. Clay Minerals, 19: 287-308. 
Morton, A.C., Hallsworth, C.R., 1994. Identifying provenance-specific features of detrital heavy mineral assemblages in sandstones. Sedimentary Geology, 90: 241-256.

Morton, A.C., Hallsworth, C.R., 1999. Processes controlling the composition of detrital heavy mineral assemblages in sandstones. Sedimentary Geology, 124: 3-29.

Nehyba, S., Opletal, V., 2016. Depositional environment and provenance of the Gresten Formation (Middle Jurassic) on the southeastern slopes of the Bohemian Massif (Czech Republic, subsurface data). Austrian Journal of Earth Sciences, 109, DOI: 10.17738/ajes.2016.0020

Nehyba, S., Šikula, J., 2007. Depositional architecture, sequence stratigraphy and geodynamic development of the Carpathian Foredeep (Czech Republic). Geologica Carpathica, 58: 53-69.

Nehyba, S., Leichman, J., Kalvoda, J., 2001. Depositional environment of the "Old Red" sediments in the Brno area (south-eastern part of the Rhenohercynian zone, Bohemian Massif). Geologica Carpathica, 52: 195-203.

Nehyba, S., Roetzel, R., Maštera, L., 2012. Provenance analysis of the Permo-Carboniferous fluvial sandstones of the southern part of the Boskovice Basin and the Zöbing Area (Czech Republic, Austria): implications for paleogeographical reconstructions of the post-Variscan collapse basins. Geologica Carpathica, 63 365-382.

Nielsen, L.H., Johannessen, P.N., 2009. Facies architecture and depositional processes of the Holocene-Recent accretionary forced regressive Skagen spit system, Denmark. Sedimentology, 56: 935-968.

Nielsen, L.H., Johannessen, P.N., Surlyk, F., 1988. A Late Pleistocene coarse-grained spit-platform sequence in northern Jylland, Denmark. Sedimentology, 35: 915-937.

Opletal, V., Filák, P., 2013. Upper Carboniferous strata reached by the exploration well Sitborice 1 beneath the Carpathian Thrustbelt units in the area of south-eastern margin of Bohemian Massif. Documenta Geonica, 2013/1, UG AVCR, Ostrava.

Otava, J., Sulovský, P., Čopjaková, O., 2000. Provenance changes of the Drahany Culm greywackes: statistical evaluation (in Czech). Geologické Výzkumy na Moravě a ve Slezsku v Roce 1999: 94-98.

Picha, F.J., Stráník, Z., Krejčí, O., 2006. Geology and hydrocarbon resources of the Outer Western Carpathians and their foreland, Czech Republic. AAPG Memoir, 84: 49-176.

Poldervaart, A., 1950. Statistical studies of zircon as a criterion in granitization. Nature, 165: 574-575.

Pupin, J.P., 1980. Zircon and granite petrology. Contributions to Mineralogy and Petrology, 73: 207-220.

Pupin, J.P., 1985. Magmatic zoning of hercynian granitoids in France based on zircon typology. Schweizerische Mineralogische und Petrographische Mitteilungen, 65: 29-56.

Reinson, G.E., 1984. Barrier-island and associated strand-plain systems. In: Facies Models (ed. R.G. Walker): 119-141. Geoscience Canada.

Rider, M.H., 1986. The Geological Interpretation of Well Logs. John Wiley and Sons, Inc., New York.
Stráník, Z., Bubík, M., Čech, S., Švábenická, L., 1996. The Upper Cretaceous in South Moravia. Bulletin of the Czech Geological Survey, 71: 1-30

Sturm, R., 2010. Morphology and growth trends of accessory zircons from various granitoids of the south-western Bohemian Massif (Moldanubicum, Austria). Chemie der Erde, 70: 185-196.

Štelcl, J., Svoboda, L., Schmidt, J., Zádrapa, K., 1977. K petrografii autochtonního paleozoika a mesozoika platformního fundamentu v podloží karpatské předhlubně a flyšového pásma (úseky "JIH" a "STŘED") (in Czech). Folia Facultatis Scientiarum Naturalium Universitatis Purkynianae Brunensis, Geologia 14: $5-120$.

Trask, P.D., 1932. Origin and Environment of Source Sediment of Petroleum. Gulf Publ. Co., Houston: 1-67.

Triebold, S., von Eynatten, H., Luvizotto, G.L., Zack, T., 2007. Deducing source rock lithology from detrital rutile geochemistry: an example from the Erzgebirge, Germany. Chemical Geology, 244: 421-436.

Triebold, S., von Eynatten, H., Zack, T., 2012. A recipe for the use of rutile in sedimentary provenance analysis. Sedimentary Geology, 282: 268-275.

Tucker, M. ed., 1988. Techniques in Sedimentology. Blackwell Science, Oxford.

Vavrdová, M., Mikuláš, R., Nehyba, S., 2003. Lower Cambrian siliciclastic sediments in Southern Moravia (Czech Republic) and their paleogeographical constraints. Geologica Carpathica, 52: 67-79.

Von Eynatten, H., Gaupp, R., 1999. Provenance of Cretaceous synorogenic sandstones in the Eastern Alps: constraints from framework petrography, heavy mineral analysis and mineral chemistry. Sedimentary Geology, 124: 81-111.

Walker, R.G., James, N.P., 1992. Facies Models: Response to Sea Level Changes. Geological Association of Canada, St. John's.

Wessely, G., 1988. Der Tiefenanschluss im Wiener Becken und der Molassenzone als Ausgangspunkt für die Alpenexploration in Österreich. Erdöl Erdgas Kohle, 104: 440-446.

Winter, J., 1981. Exakte tephro-stratigraphische Korrelation mit morphologisch differenzierten Zironpopulationen (Grenzbereich Unter/Mitteldevon, Eifel-Ardennen). Neues Jahrbuch für Geologie und Paläontologie, Abhandlungen, 162: 97-136.

Wojewoda, J., Nehyba, S., Gilíková, H., Buriánek, D., 2015. Devonian siliciclastic rocks of the Babí lom locality (southern Moravia, Czech Republic): sedimentary environment reconstruction and provenance study. Geological Quarterly, 59 (1): 229-238.

Zack, T., von Eynatten, H., Kronz, A., 2004a. Rutile geochemistry and its potential use in quantitative provenance studies. Sedimentary Geology, 171: 37-58.

Zack, T., Moraes, R., Kronz, A., 2004b. Temperature dependence of $\mathrm{Zr}$ in rutile: empirical calibration of a rutile thermometer. Contributions to Mineralogy and Petrology, 148: 471-488.

Zecchin, M., 2007. The architectural variability of small-scale cycles in shelf and ramp clastic systems: the controlling factors. Earth-Science Reviews, 84: 21-5.

Zimmerle, W., 1979. Accessory zircon from rhyolite, Yellowstone National Park (Wyoming, U.S.A.). Zeitschrift der deutschen Geologischen Gesellschaft, 130: 361-369. 